University of Wollongong

Research Online

Faculty of Business - Papers (Archive)

Faculty of Business and Law

$1-1-2014$

Financial accounting reform: the need for a 'back to basics' approach for profit measurement and wealth measurement

John Ryan

University of Wollongong, jryan@uow.edu.au

Follow this and additional works at: https://ro.uow.edu.au/buspapers

Part of the Business Commons

Research Online is the open access institutional repository for the University of Wollongong. For further information contact the UOW Library: research-pubs@uow.edu.au 


\title{
Financial accounting reform: the need for a 'back to basics' approach for profit measurement and wealth measurement
}

\author{
Abstract \\ By recognising the dual purposes of financial accounting, and developing distinct theories to guide the \\ preparation of financial reports, the apparent internal contradictions in accounting theory can be resolved. \\ Property rights and measurement theory provide the basis for explaining transaction-based profit \\ measurement and funds commitment, and for a statement of wealth measured using market prices. \\ Property rights are recognised in The New Institutional Economics. Going beyond accepted accounting \\ conventions, property rights provide the qualitative, empirical property giving meaning to accounting \\ practice for profit measurement through the 1940s to 1960s. Examples of profit and of wealth \\ measurement are included.

\section{Keywords} \\ financial, approach, profit, measurement, reform, wealth, need, back, accounting, basics

\section{Disciplines} \\ Business

\section{Publication Details} \\ Ryan, J. (2014). Financial accounting reform: the need for a 'back to basics' approach for profit \\ measurement and wealth measurement. International Journal of Economics and Accounting, 5 (1), 1-50.
}




\title{
Financial accounting reform: the need for a 'back to basics' approach for profit measurement and wealth measurement
}

\author{
John B. Ryan \\ School of Accounting and Finance, \\ University of Wollongong, \\ NSW 2522, Australia \\ E-mail: jryan@uow.edu.au
}

\begin{abstract}
By recognising the dual purposes of financial accounting, and developing distinct theories to guide the preparation of financial reports, the apparent internal contradictions in accounting theory can be resolved. Property rights and measurement theory provide the basis for explaining transaction-based profit measurement and funds commitment, and for a statement of wealth measured using market prices. Property rights are recognised in The New Institutional Economics. Going beyond accepted accounting conventions, property rights provide the qualitative, empirical property giving meaning to accounting practice for profit measurement through the 1940s to 1960s. Examples of profit and of wealth measurement are included.
\end{abstract}

Keywords: financial accounting theory; postulates and principles; property rights; qualitative empirical property; realisation; cost allocation; recoverable cost; wealth measurement; contracts; measurement theory; monetary profit measurement.

Reference to this paper should be made as follows: Ryan, J.B. (xxxx) 'Financial accounting reform: the need for a 'back to basics' approach for profit measurement and wealth measurement', Int. J. Economics and Accounting, Vol. X, No. Y, pp.000-000.

Biographical notes: John B. Ryan is an Honorary Professorial Fellow at the University of Wollongong, where he was the Foundation Professor of Accounting from 1973 to 1988 . Subsequently, he was Dean of Commerce at the Auckland University of Technology, Associate Professor University of Auckland, and University of Western Sydney, where he was Head, School of Accounting, 2004-2006.

\section{Introduction}

Property rights are at the centre of capitalism, and all economic activity, providing the motivation for the earning of profit by increasing the owners' stock of them. Property rights are a necessary part of the institutional arrangements legislated by governments to facilitate the functioning of the economy, and they provide the motivating force for accumulating wealth as well as for the earning of profit [Stiglitz, (1993), p.31]. They are the means for holding assets, and for acknowledging obligations or debts. Hence, they 
have an important accounting as well as economic function. Property rights emerged along with double entry bookkeeping as part of the flowering of the Renaissance in the Italian city states of Florence, Genoa and Venice. "Private property (power to change ownership)" was listed first by Littleton (1933, p.13) in his eight "antecedents of bookkeeping".

The motivation for this paper is to explain property rights, and changes in them, as the objects of measurement for calculating periodic accounting profit. Reform centred on 'back to basics' involves re-evaluating accounting fundamentals, the basic elements of the accounting equation. These are the terms with which we are all familiar, like assets, liabilities, owners' equity and profit. But they are all general terms, and the fact that different people have interpreted them differently has led to much misunderstanding and/or disagreement in accounting theory. How can these general terms be infused with specific meaning? What is new, perhaps startling, is that property rights can provide the key to the solution of this problem which involves deriving the property to be measured from selected information needs of shareholders. This is demonstrated for monetary profit measurement for the information needs of money capital maintenance and stewardship of money funds in a specific purpose application of the general accounting system.

However, being anchored in cost measures, the conventional balance sheet cannot measure liquidity, nor can it provide an overall measurement of wealth. The need for a separate statement of wealth was recognised by Joplin in 1914 when he argued that "increased values in assets must be shown in the Balance Sheet (parenthetically) or in another schedule"1. Hence, a secondary motivation is to demonstrate how the specific purpose approach enables the production of a separate statement of wealth in which assets and liabilities are measured at their current market prices. The relevant information needs associated with the wealth statement are for calculation of liquidity and solvency, and asset backing per ordinary share. This specific purpose approach contrasts with the general purpose approach of standard setters.

The tension between measurement of profit as a (realised) money gain, and measurement of wealth in current prices is a continuing challenge for external financial reporting. For example, Edwards (1938) advocated present values as the economic alternative he preferred to historical cost accounting. MacNeal (1939), Edwards and Bell (1961), Moonitz (1961), Chambers (1966) and Sterling (1970) advocated current market values. Earlier, Alexander (1950, p.94) had noted that the "bewildering number of concepts of income ... can be narrowed down to three main issues. These are the real versus the money measure, inclusion versus exclusion of capital gains, and accrual versus realization as the criteria for timing of a gain or loss”. The dual reporting system outlined in this paper addresses these issues. Today, with misgivings in some quarters, fair value appears to be the concept increasingly favoured by the FASB and IASB. But the application of fair value in accounting standards has failed to provide consistent solutions ${ }^{2}$, and the challenge remains.

The hearings conducted by the United States Securities and Exchange Commission (2008) on mark to market accounting reveal equally strong views on both sides of this debate. Preparers deplored the excessive volatility flowing from the use of fair values, while investors valued their transparency and comparability. A strong demand for financial information relevant to the information needs directly relevant to both preparers and users is thus evident, and could be met by 'specific purpose' financial statements for measuring periodic profit on the one hand, and wealth on the other hand. 
Several essential or crucial aspects of property rights warrant emphasis. In their review of the property rights literature, Furubotn and Pejovich (1972, p.1139), emphasised that property rights refer not to relationships between people and things, but rather "the sanctioned behavioural relations among men that arise from the existence of things and pertain to their use". Further, these authors define the prevailing system of property rights "as the set of economic and social relations defining the position of each individual with respect to the utilization of scarce resources”, and claim agreement on this definition from Roman law, common law, Marx and Engels, and current legal and economic studies.

Features of property rights which make generalising about them difficult are the view of them as a 'bundle of distinct rights', and, second, their incomplete nature. While the specific rights may vary depending on the object owned, they normally include "the rights to possess, use, use up, abuse, lend, let on hire, grant as security, gift, sell, and bequeath the object” [Walker, (1980), p.1007]. The significance of full ownership is that it grants the owner exclusive use of the particular asset. Their incomplete nature means that the ultimate effect of property rights may be difficult to foresee due to the impossibility of the contracts changing them being able to specify fully all the future conditions under which they may need to be interpreted and applied (Hart, 1993). Complex issues are raised, due also in part to the fact that property rights are constantly changing.

The remainder of the paper is organised as follows. First, my theoretical framework and the research methods utilised are outlined. The double entry calculus (DEC) and the general postulates of financial accounting are included in Appendix A. The opportunity is taken to acknowledge my reliance on other writers. The changing face of the economic framework assumed as relevant to accounting is reflected in the section which follows, with property rights specifically recognised in the New Institutional Economics (NIE). The central explanation of the paper - the measurement of monetary profit over the 1940s to the 1960s - is next elaborated; first generally, commencing with information needs and then proceeding to the more detailed explanation of how property rights underpin the basic principles. The need for a separate statement of wealth is then explained using the property right of 'the right of sale' to justify measurement in current market prices. Appendix B shows examples of the financial statements of the two measurement systems. Concluding comments bring together the several threads in an overall evaluation.

\section{Theoretical framework and research methods}

In this part, the relevant features of my theoretical framework and the research methods utilised are highlighted. The full framework includes a set of general postulates and definitions relating accounting to the environment in an essentially 'principles-based' system. These postulates are formally presented in Appendix A. The centre-piece of this system is the DEC, defined as the general axiomatic system describing the relationships between assets, liabilities and owners' equity, including transactions changing them, for profit and wealth measurement. The relationship between postulates and principles is elaborated, my debt to Mattessich (1964b) is acknowledged, and the reasons for using Rudner's (1966) concept of a theory are explained. Content analysis is used in the historical part to demonstrate the relationship between the accounting principles of my theory, and accounting practice during the 1940s to the 1960s. 


\subsection{Postulates}

Mattessich (1984, p.28) stated that Paton (1922) "deserves the highest recognition” for being "the first to search for the analytical and empirical premises on which accounting rests". However, he charged Paton with "putting the cart before the horse” as Paton's postulates were consigned to his final chapter. Examples of other relatively early writers to employ a similar method were Chambers (1955, 1957, 1960, 1963, 1966), Ijiri (1967, 1975), Moonitz (1961) and Mattessich (1957, 1964b). Their research methods can be broadly described as "postulational” (Gaffikin, 1988; Mattessich, 1995). Chambers (1963) in particular is credited with making a significant contribution to the development of accounting theory by emphasising the need for postulates (assumptions or axioms) external to accounting practice, and logical relationships, from which accounting principles can be derived (Gaffikin, 1988). It is in this sense that postulates and principles are related in my framework ${ }^{3}$.

\subsection{Postulates and 'a true and fair view'}

Due to the significance attached to the 'true and fair view' legal requirement, its treatment within my overall framework is explained briefly. My first and final postulates read as follows:

1 The objective of financial accounting is to provide users with relevant and reliable accounting information for their recognised financial information needs.

7 Financial statements prepared in accordance with these postulates will provide a true and fair view of the information disclosed for the information needs recognised.

Relevant information is defined independently of reliable information, and no 'trade-off' between them is permitted. Normally all relevant information should be disclosed, and if some information does not meet reliability criteria, then it should be appropriately qualified.

It is assumed that that the relevance and reliability criteria can be aligned with the requirement to give a true and fair view. The brief explanation for this is that 'true' is given a similar meaning to 'reliable', meaning that the reported measurements 'faithfully measure the property they purport to measure', and that the measurements are verifiable (by a qualified measurer); and 'fair' is equated with 'relevant'; meaning that the information disclosed is suitable for the information needs recognised. Fair also has the connotation of not being misleading. Arguably the concept of 'not being misleading' places a responsibility on the reporting entity to disclose what is being measured, implying that the basic concepts are clearly communicated. In addition, any information serving an alternative purpose would need to be clearly distinguished.

A further connotation is that different information needs requiring different measurement bases may call for separate statements. In summary, if the information needs recognised are clearly identified, and if the property derived as the object of measurement is faithfully measured and disclosed, then, and only then, will the financial statements reporting the relevant accounting information provide a true and fair view of that information. 


\subsection{Mattessich’s influence}

In several publications Mattessich (1964a, 1972) advanced a theory of accounting, major features of which are reflected in my structure. His exposition attempted "a set-theoretical formulation" [Mattessich, (1964a), p.446] aimed at reducing the foundations of accounting to the notions of "ownership and debt claim", both of which he regarded as empirical notions. Property claims (ownership rights, or in aggregate for an accounting entity, the owners' equity) were included in Assumption 6 of his basic theory [Mattessich, (1964a), p.36]. Further, the 1977 Preface to the Reprint edition listed as one of the "most important improvements" the inclusion of a further assumption at No. 10 contained "only implicitly in the English version”. That assumption read:

\footnotetext{
"There exists a specific information need and purpose (to be specified and) to be served by the pertinent accounting system. The specific hypotheses (for which the surrogate assumptions 10 to 18 - or 11 to 19 in the German version - reserve a place) will then depend on the information need specified in the hypothesis chosen under this (new) assumption.” [Mattessich, (1964b), p.xx]
}

He accepted that rules of interpretation were required to confer meaning on the general system, and that the "testing of a general accounting theory by way of the empirical verification or refutation of its interpreted systems, seems to me the only way of conforming to the requirements of an empirical discipline” [Mattessich, (1972), p.486]. However, although he appreciated that "purely abstract or nonempirical accounting theories" cannot exist, he later appeared to argue for a special status for instrumental hypotheses as the means for conferring meaning on his accounting calculus. These hypotheses were characterised as "goal-oriented", of an "imperative" type and being "highly efficiency responsive", with "their acceptance criteria" based on these two characteristics [Mattessich, (1995), pp.121-22]. By advocating these different criteria for their acceptance, doubts were raised about his ontology and his example of a simplified instrumental hypothesis for capital maintenance of a minority shareholder was not convincing (Archer, 1998). The different treatment proposed offends Suppe's (1977, p.117) point that "no distinction between direct-observation and nondirect-observation terms may be assumed"; that is, all terms should be evaluated using similar criteria.

Further, Mattessich's (1995, pp.130-133) use of structuralism to help explain the correspondence between theory and reality likewise was not convincing, Archer (1998, p.305) writing that "it is far from clear how Mattessich's bridge between structuralism and realism applies to accounting”. If special status is not sought for the auxiliary propositions, these criticisms largely disappear as all statements within the theory can then be evaluated using the usual logical and empirical criteria. Mattessich (1995) extended the restrictive accounting interpretation of reality as "phenomena which have physical form ..." [Vickrey, (1976), p.34] to include social reality. His overall approach appears sound, and can be applied consistently. The extent of my reliance on his approach is evident in the explanation which follows.

\subsection{Converting the calculus into a theory}

The formal representation of the elements of the accounting equation in the DEC shows the relationships between the accounting elements. Changes in assets and liabilities are the primitive terms of this calculus. Strengths of the axiomatic method are, first, the clear, 
deductive relationship established between the accounting elements, and between the axioms (postulates, premises or assumptions) and the theorems (conclusions). Robbins (1937, p.66) stated that "[s]cientific generalisations, if they are to pretend to the status of laws, must be capable of being stated exactly"4, which he distinguished from "quantitative exactitude".

A second strength is that the means for conferring specific meaning on the general accounting system must be stated explicitly. Postulate 4 sets out the steps for deriving a specific interpretation of the accounting elements from selected information needs of users. This approach forces the theorist to be fully aware of the information needs recognised, and the corollary that those needs determine the property to be measured in financial statements. It should be clear that this is a specific purpose approach, as opposed to the general purpose approach applied under professional conceptual frameworks. This specific purpose approach provides a bridge to the measurement requirement for selection of an extensive, empirical property capable of embracing all the accounting elements.

\subsection{Measurement theory criteria}

Paton and Littleton (1940, pp.12-13), recognising that "cost” was "hardly broad enough" as the "basic subject matter of accounting", preferred instead "price aggregates resulting from exchanges [as] a much needed device for coordinating a number of related concepts”. For them, price aggregates was the property to be measured in accounts, arguing that it "is the best means for representing varied transactions in homogenous terms". Two decades were to pass before accounting was accepted as a measurement function (Bierman, 1963). Measurement theory describes the property to be measured as the qualitative, empirical property, and certain conditions govern its selection. Accounting theorists who have supported the application of measurement theory to accounting include Mattessich (1964a), Chambers (1965), Sterling (1970), Vickrey (1970), Willett $(1987,1988)$ and Salvary (1989). Stevens' (1946, p.680) statement that the application of "a consistent set of rules" for a stated purpose constitutes measurement appears broad enough to include accounting.

As an empirical relational structure, the measurement system must satisfy two fundamental theorems, namely, the representation and the uniqueness theorems. The representation theorems are designed to ensure the additivity of the qualitative, empirical property. The uniqueness theorem shows how a particular numerical scale can be converted into another numerical scale by multiplication by a constant while at the same time preserving the integrity of the empirical measurements. This theorem is important for the use of the ratio scale, the scale of relevance to accounting. The empirical relation system should establish an ordering relation amongst the property being measured, and provide for its concatenation. The ordering relation is represented by 'greater than', and concatenation (additivity) by 'equality' [Krantz et al., (1971), p.5, 71; Luce and Krumhansl, (1988), p.9]. The monetary scale (using the local currency) is assumed to be the relevant scale for reporting measurements in financial statements to shareholders in a particular jurisdiction. The concept of a theory in which these ideas are utilised is next explained. 


\subsection{Rudner (1966)}

Rudner's (1966, p.10) concept of a theory as “a systematically related set of statements, including some lawlike generalisations, that is empirically testable" is used. The relationship between the statements is deductive or logical; and some of the statements, due to their explanatory or predictive power within the theory, are designated as "lawlike" 5 . The theory is empirically testable, meaning that at all points where its concepts or statements relate to reality, they are testable against that reality, and thus are open to being refuted (Popper, 1959). Popper (1959) appears to have left two legacies to the philosophy of science; first, his simple and straight forward approach to objectivity, and secondly, his insistence that a critical approach is crucial to "rational discussion" in which problems are stated clearly and the solutions proposed are examined "critically" [Popper, (1959), p.16].

For those unfamiliar with Rudner (1966) his approach provides a means to solve the problem of how to choose the relevant concept of profit from the several then being debated. His distinction between purely formal systems (a calculus) and interpreted systems (full theories) enables the 'bones' of the system (the structure of the system - the elements and their relationship) to be evaluated independently of particular applications. An advantage of this approach is that financial accounting can be constructed initially as a general system with the accounting concepts of assets, liabilities, and owners' equity defined in general terms. The next stage comes when a particular purpose or application is identified, and decisions are required regarding the meaning to be conferred on these key concepts. For example, if wealth is to be measured, current market prices are relevant. Formally, rules of interpretation are required which enable meaning to be conferred on the general system. The particular theory can then be tested to see if the resultant statements satisfy the user needs for which they were developed. This is a specific information needs approach.

\subsection{Crisis in financial accounting theory}

The accounting and philosophical context has changed markedly since Rudner (1966). Some may have viewed the decade of the 1960s as one of progress, particularly in the development of deductive models of income measurement, but no one model attracted a consensus, and the 1970s threw up several challenges. Using Kuhn's (1970) concept that progress in science is through revolutions, Wells (1976) argued that the historical cost system was in crisis, largely because it was unable to deal with one, intractable anomaly; namely, failing "to take account of changes in asset prices and changes in the purchasing power of the monetary unit” [Wells, (1976), p.476]. No consistent and coherent theory explaining external financial accounting has been accepted.

Mouck (1989, p.104) drew attention to the "most basic irony" that "accounting researchers were 'awakened' to the scientific method during the same decade (the 1960s) that witnessed the disintegration of the 'the received view' of scientific methodology as a result of the 'growth of knowledge' debate”. Suppe (1977, p.115) reached a similar conclusion in respect of the "Received View", writing that "a general consensus that the Received View is inadequate now seems to hold among most philosophers of science" but there is "no general consensus what the source of its inadequacy is". In his Introduction Suppe (1977, p.135) noted that Kuhn viewed the evolution of science "as fundamentally discontinuous", and later, in his Afterward written eight years after the 
1969 symposium on the structure of scientific theories, Suppe (1977, p.647) concluded that Kuhn's views "have undergone a sharply declining influence”.

\subsection{Response to Cushing (1989)}

Nevertheless, in attempting "a Kuhnian interpretation of the historical evolution of accounting”, Cushing (1989, pp.36-37) concluded that, first, "the double entry model has been remarkably resilient", and second, that "the advent of standard-setting radically transformed the nature of accounting, and precipitated a crisis in the accounting discipline”. This in turn led to the search for accounting principles, with the lack of success in that search inducing a more severe crisis. He charged that "this crisis is characterised by four fundamental problems none of which can be resolved in a scientifically acceptable manner in the context of the double-entry accounting paradigm. These are that:

1 accounting is inherently arbitrary (Thomas, 1969, 1974)

2 accounting has been politicized (Solomons, 1978; Zeff, 1978)

3 rational selection of normative accounting standards is impossible

(Demski, 1973, 1974)

4 the role of accounting scholars has been to supply 'excuses' to competing groups seeking to influence accounting standards to further their own interests

(Watts and Zimmerman, 1979)” [Cushing, (1989), p.37].

My response to the 'four fundamental problems' identified by Cushing is as follows. First, Thomas (1974, p.4) conceded that "though allocations for single purpose reports can be defended in terms of their satisfying a purpose, no such defence is available to general-purpose financial accounting allocations" (my italics). The necessity and role of allocations for the purpose of periodic monetary profit measurement being purposeful, as explained later, are thus not subject to the first criticism. Second, with the process of setting accounting standards becoming more independent of national governments, 'politicisation' may be expected to diminish. However, given that accounting standards have the ability to change the distribution of economic resources, national intervention cannot be completely ruled out. But any government intervening would clearly be identified, and could be expected to explain its position. Third, accounting is a contrivance, constructed for the benefit of people, and as such, it should be possible to ascertain the source of that benefit, and then to 'rationally select' rules to achieve that benefit. The purpose of theorising is to contribute to that process. Fourth, while Watts and Zimmerman (1979) may correctly have identified the role of some accounting scholars, their broad generalisation is not accepted.

Cushing (1989, p.37) went on to claim that "the most devastating effect of these conditions has been that many of today's leading scholars no longer display an interest in addressing the fundamental issues of accounting, but have instead gravitated toward the more scientifically satisfying study of the paradigms in other disciplines that are related to accounting". Archer (1993, p.64) drew attention to this problem from another perspective, writing that: 


\begin{abstract}
“... the main thrust of the theoretical work in financial accounting is no longer directed to finding a conceptual basis for accounting conventions: rather it is concerned with understanding the economic role and consequences of such conventions and of the institutions which develop and promulgate them."
\end{abstract}

Further, also writing from a Kuhnerian perspective, Mouck (1993, p.33) argues that the switch within the economics paradigm was from the "economic income perspective" to an "informational perspective", largely because the former failed to "identify research problems and provide methods of guidance”.

\title{
2.9 Continuing usefulness of Rudner's theory
}

Rudner's (1966) theory seems sufficiently robust to accommodate criticisms of the scientific method like those of Suppe (1977, p.115), who listed nine characteristics which "an adequate analysis of theories must possess". Regarding alternatives, Suppe (1977, p.709) stated that the semantic conception of theories is the "only serious contender" to emerge as a replacement. This approach construes theories "as extralinguistic entities that admit of alternative and even inequivalent linguistic formulations. Structurally a theory consists of a domain of states of phenomenal or physical systems together with one or more laws". By including "extralinguistic entities" and "laws" this approach appears broad enough to encompass my application of Rudner's (1966) concept of a theory ${ }^{6}$ to the task of producing a consistent and logical explanation of accounting principles and conventions for the period of the 1940s to the 1960s within a relevant institutional framework.

\subsection{Historical analysis}

The historical analysis draws mainly on secondary sources in searching the writings of leading academics, practitioners, professional bodies and committees for evidence in support of the monetary concepts. Qualitative content analysis (Berg, 1998; McWalters, 1998) is employed in assessing the extent to which a writer's understanding accords with the meaning of the monetary concepts. Support may range from simply affirming the cost basis to an explanation covering the substantive concepts and rules for recording assets and liabilities, and for measurement of periodic monetary profit.

\section{The economic framework assumed and property rights}

Realistic economic assumptions relevant to business and accounting practice are difficult to find, particularly from microeconomics. For example, except for a confirmatory, information role, accounting is redundant in the world of neoclassical economics ${ }^{7}$. Assumptions such as perfect competition, certainty and full and complete markets do away with the need of accounting for decision making. Behavioural finance economists (for example, Shleifer, 2000; Montier, 2002; Shiller, 2005) also question the relevance of these assumptions. The economic context assumed is based on the institutions at the heart of capitalism, namely, property rights, contracts, money and the changes in them, including those which are part and parcel of "true uncertainty" (Knight, 1921).

These institutions are recognised in macroeconomics, particularly developments in the Post-Keynesian model (Davidson, 1981). Moreover, the NIE, including transaction 
cost economics (TCE), specifically emphasises property rights and contracts as well as the governance role associated with their monitoring and enforcement. Nevertheless, in spite of the demonstrated weaknesses of the neoclassical economic model for measurement of profit for a past period ${ }^{8}$, a growing culture of reliance on traditional economic theory is evident in the 'closely collaborating' FASB and IASB (Schipper and Vincent, 2003; Barth, 2007). Yet a notable economist had provided an early lead in another direction.

\subsection{Fisher's (1906) lead}

Fisher (1906, p.vii) described his book as "an attempt to put on a rational foundation the concepts and fundamental theorems of capital and income. It therefore forms a sort of philosophy of economic accounting, and, it is hoped, may supply a link long missing between the ideas and usages underlying practical business transactions and the theories of abstract economics". His book represents a major attempt to apply the concepts of wealth and property rights to business, including accounting. His definitions of wealth and property rights follow. Wealth is used "to signify material objects owned by human beings" [Fisher, (1906), p.3]. Hence, wealth must be material (economic) and it must be owned. By ownership, Fisher (1906, p.18) meant the right to use it, which he called a property right. His complete definition reads: "A property right is the right to the chance of obtaining some or all of the future services of one or more articles of wealth". By identifying the two necessary and sufficient conditions for recognition of an asset Fisher (1906) made an excellent start to his "philosophy of economic accounting"9.

In further elaboration, he continued: "Wealth and property, then, are correlative terms. Wealth is the concrete thing owned; property is the abstract right of ownership. The two concepts mutually imply each other” [Fisher, (1906), p.22]. It is worth noting that the 'correspondence' between wealth and property rights is contemporaneous, hence existing or present property rights are rights to the use of existing wealth, here and now, for the chance of obtaining a future service or benefit. Thus it is the existing wealth that constitutes the present wealth, and which is relevant for measurement of the current position, rather than the problematic future benefits. Hence, "it is impossible to have a right to any future wealth which is not also a right to some present wealth as a means of securing that future wealth" [Fisher, (1906), p.33].

His definitions of wealth and property rights provided the essence of assets and ownership, but unfortunately, they have not been reflected in accounting theory. Further, Fisher (1930, p.68) also understood clearly the central role of transactions in accounting. Frankel (1949), in criticising Fisher's concept of psychic income, endorsed his emphasis of transactions as the basis for measurement in accounting. In his review of Canning (1929b), Fisher (1930) demonstrated in a clear summary that he understood the nature of periodic profit measurement as adjusted cash flow, but without relating this exposition to changes in property rights arising from the related transactions.

Canning (1929b), Fisher's disciple, appreciated the need for a qualitative, empirical property, but was unable to interpret all of the accounting elements using his first choice of 'future services'. By the end of his book, however, money as in "money-valued income" and "money-valued outgo" had come to rival services as the integrating property, and his definition of assets and liabilities appears to give equal weight to services and to money [Canning, (1929b), p.14]. Later, Canning (1933) accepted the transactions basis for measurement of periodic profit, but without discussing the 
underlying qualitative, empirical property ${ }^{10}$. Apparently, following his renunciation of classical and neoclassical economics, he did not see any need to reconsider his earlier candidate of future services (Canning, 1929a).

\title{
3.2 Property rights in economic theory
}

The significance of property rights in economic theory were recognised in the work of Coase $(1937,1959,1960,1992)$ and Demsetz (1967, 1995), while complementary developments in agency theory portrayed the firm as a "nexus of contracts" (Jensen and Meckling, 1976). Coase (1937), in seeking to explain the existence of the firm, outlined the basis for TCE although it was to be many years before his ideas were developed. His 1959 article on the allocation of radio stations included the following exposition of the centrality of property rights:

\begin{abstract}
“A private-enterprise system cannot function properly unless property rights are created in resources, and, when this is done, someone wishing to use a resource has to pay the owner to obtain it. Chaos disappears; and so does the government except that a legal system to define property rights and to arbitrate disputes, is, of course, necessary.” [Coase, (1959), p.14]
\end{abstract}

These ideas were used in his 1960 article on the theory of social cost to challenge the conventional treatment of externalities. Coase (1992, p.717) described the influence of this paper on legal scholarship as "immense". Demsetz (1967, pp.347-348) sought to "fashion some of the elements of an economic theory of property rights", leading him to emphasise the "close relationship between property rights and externalities" and to state that a "primary function of property rights is that of guiding incentives to achieve a greater internalization of externalities". This narrow characterisation of property rights, while suiting Demsetz's (1967) purpose, can be contrasted with their motivating force for maximising profit and wealth. Williamson (2000, p.599) postulates that concentration on ex ante motivation, and Coase's claim that "chaos disappears", resulted in the early property rights literature overplaying its hand, and provided an opening "through which the governance of contractual relations walked in during the 1970s".

\subsection{The NIE}

Williamson (1985, p.26) developed an approach complementary to property rights, described as TCE. Neoclassical economics was criticised as a "black box"11. He located his approach "in the efficiency branch of contract" as part of the NIE. Later, drawing on the social framework for economic development outlined by North (1994), he summarised the overall approach of NIE using four levels; social policy, the broadest level, reflects the customs, traditions and norms (including religion) of society, with change in them perhaps taking generations. The second level describes the institutional environment, including the "formal rules of the game". Here the "definition and enforcement of property rights and of contract laws are important features" [Williamson, (2000), p.598]. The third level, governance, encompasses rules for the "play of the game - especially contract" and the fourth level is the coal face of economic activity, resource allocation and employment. Ex post adjustment of contracts would fit naturally at this fourth level. 
Williamson (1985, p.29) also points out that TCE "maintains that it is impossible to concentrate all of your bargaining at the ex ante contracting stage. Instead, bargaining is pervasive - on which account the institutions of private ordering and the study of contracting in its entirety take on a critical economic significance". In a review of the contribution of Douglas North to the NIE, Menard and Shirley (2011, p.5) describe the three key concepts of NIE (TCE, property rights and contracts) as its "golden triangle". Relevant research on all three concepts has the potential to enlighten accounting theory. The accountability aspect of external financial reporting fits naturally within the governance function of NIE.

It cannot be claimed that this brief summary does justice to this new line of enquiry. Its introduction here signals an economic alternative to the dominant neoclassical theory; an alternative that promotes the assumption of institutions supporting the need for accounting. Taken seriously, NIE should trigger a review of neoclassical economics. However, to date there has been virtually no reference to the role of accounting and auditing in this research, apart from a brief reference in Williamson (2000, p.606). Accountability could be expected to be included specifically in level 2 (design), 3 (governance) and 4 (play of the game, actual transactions). It may be significant for accounting that the transaction is considered to be "the basic unit of analysis" [Williamson, (2000), p.599].

However, innovative research has not entirely by-passed accounting. The research of La Porta, Lopez-de-Silanes, Sheilfer and Vishny (LLSV, 1997, 1998) ${ }^{12}$ examining legal rules for the protection of shareholders and creditors in 49 countries in two papers includes an analysis of the effectiveness of accounting standards. The evidence confirmed their "basic hypothesis that being a shareholder, or a creditor, in different legal jurisdictions entitles an investor to a very different bundle of rights. These rights are determined by laws; they are not inherent in the securities themselves" [LLSV, (1998), p.1151]. The major differences in the laws were found between those originating in "the common law tradition" and those originating in the "civil law tradition", particularly that of France, the former tending to offer investors considerably more protection. German-civil-law and Scandinavian countries, sitting between the two traditions, had "the best quality of law enforcement".

Regarding accounting they wrote: "Accounting plays a potentially crucial role in corporate governance. For investors to know anything about the companies they invest in, basic accounting standards are needed to render company disclosures interpretable. Even more important, contracts between managers and investors typically rely on the verifiability in court of some measures of firm's income or assets” [LLSV, (1998), p.1140]. Table 5 [LLSV, (1998), pp.1142-1143] presented country scores for the various rule of law measures, as well as for their accounting standards. On the quality of accounting, Scandinavia (rating 74) is still top, common law countries second (69.62), and German civil law third (62.67).

\section{Monetary profit measurement}

The aim of this part is to explain monetary profit measurement initially in general terms to provide an overview, and then to explain in more detail the derived principles of realisation and cost allocation, the latter including the recoverable cost rule. The more detailed explanation provides the direct link to measurement of changes in property 
rights, and mainly draws on accounting writers of the 1930s and 1940s, whose writings supported the practice of corporate accounting over the period of the 1940s to the early 1960s, the time during which historical cost became the accepted method. But first it is important to define the concept of profit clearly so that it captures the duality of cash flows, positive and negative, on which profit measurement is based in contrast to the single dimension denoted by historical cost.

The term 'monetary profit', used ${ }^{13}$ by the Institute of Chartered Accountants in England and Wales (ICAEW) in 1952 in Recommendation N15 Accounting in Relation to Changes in the Purchasing Power of Money captures the essence of profits computed under historical cost. Paragraph 1 includes the following statements:

\begin{abstract}
"Similarly a profit and loss account is an historical record. It shows as the profit or loss the difference between the revenue for the period covered by the account and the expenditure chargeable in that period, including charges for the amortisation of capital expenditure. Revenue and expenditure are brought into account at their recorded monetary amounts. This basis is frequently described as the historical cost basis and in this statement the expression "monetary profits" is used to denote profits so computed."
\end{abstract}

Similar terms were used by the ICAEW in evidence to the Company Law Committee (1962) and quoted with approval by that committee, as shown later. Thus, throughout this paper, the term 'monetary profit' is preferred to historical cost as a more accurate description of the object of measurement, particularly as historical cost accounting has incorporated measurements not supported by transactions and changes in property rights; income tax allocation, for example.

\title{
4.1 Overview
}

Fisher's (1906) concept of property rights is adopted as the underlying qualitative, empirical property of the accounting elements, the objects of measurement. Second, transactions are accepted as the fundamental measurements (Canning, 1929a, 1929b; Fisher, 1930; Littleton, 1933; Mattessich, 1964a; Ijiri, 1967; Willett, 1987, 1988). Derived from executed contracts, transactions are the primary means by which changes in property rights are measured, the contract consideration stipulating the amount of the relevant transaction. Whether it is the first contract entered into by a company, perhaps with its shareholders, or a later one when the company proceeds to trade, each contract executed by the company changes its property rights.

Hence, the money amounts stipulated in transactions derived from contracts provide the basis for measurement of changes in property rights. Money and contracts are intimately related [Davidson, (1972), p.xiv], as, in addition to its significance for settlement of debts and contracts, money assumes the function of "money-of-account" [Keynes, (1930), p.3] for use in profit measurement. This function is important as it gives businesses some certainty in respect of the cost to be recovered in order to return a profit. The money-of-account function would be lost if money (the domestic currency) was no longer accepted for the settlement of debts, and other currencies were used for that purpose.

Third, Mattessich's (1964b, 1972) general structure, based on the relationship between the general accounting system (uninterpreted calculus) and rules of interpretation by which specific meaning is conferred on the whole system, is central to my explanation. The rules of interpretation enable specific meaning to be conferred on 
the general accounting elements from financial information needs of shareholders. This process commences with the identification of the common financial information needs of ordinary shareholders, and proceeds by selecting compatible needs that can be met in a single interpretation of the general accounting system. Needs so met are described as 'recognised'. 'Common' refers to financial information needs that apply to a class of shareholders. Information needs are returned to following completion of this overview.

The Executive Committee of the American Accounting Association (1936/1957) published the Tentative Statement of Accounting Principles Affecting Corporate Reports, a notable statement for several reasons. It was the first statement on accounting principles issued by a professional body. The Executive Committee included W.A. Paton and A.C. Littleton, Director and Assistant Director of Research respectively. Drafted by President E.L. Kohler and H.C. Greer the Tentative Statement unequivocally supported the 'cost basis'. Extensive discussion, fuelled by the Executive Committee's determination to make a positive contribution, "eventually produced agreement on every major point” [Zeff, (1966), pp.44-45], a truly remarkable achievement. The main motivation for its preparation was to provide authoritative guidance to the recently established SEC. C.G. Blough, first Chief Accountant at the SEC, praised it as "a real contribution to the accounting profession" [Zeff, (1966), p.46]. Apparently, the SEC's "accounting staff frequently cited the Tentative Statement with favour as well as the revisions thereof issued in 1941 and 1948 and the eight supplementary statements issued between 1950 and 1954” [Zeff, (1999), p.90]. In a further accolade, Zeff (1999, p.90) described the Tentative Statement (AAA, 1936/1957) as a "paean" to historical cost accounting.

Paton and Littleton (1940), building on the Tentative Statement, produced their classic book described by Zeff (1999, p.90) as "perhaps the most influential monograph in the U.S. accounting literature ... Above all, it was an elegant explication and rationalization of the historical cost accounting model that was already widely accepted in the U.S. It met with general acclaim and was used for many years in accounting courses throughout the country". In a remarkable act of endorsement, the monograph was distributed jointly by the AAA and the American Institute of Accountants as a dividend to their respective members [Zeff, (1966), p.49].

Across the Atlantic, credit for fashioning the common law rule that dividends were to be paid only from profits, and that capital was to be maintained at the money amount contributed by shareholders was given to Jessel, Master of the Rolls in his interpretation of the Companies Act 1862 [French, (1977), p.307]. In Flitcroft's case decided in 1882 Jessel enunciated the concept "of an implied contract with creditors ... [who] give credit to the company on the faith ... that the corporation shall keep its capital and not return it to shareholders” [Yamey, (1962b), pp.429-430]. The economist, John Stuart Mill (1891), emphasised the need for financial statements to provide information relevant for capital maintenance, and stewardship. Andrews (1949, p.71), another economist, explained the capital maintenance rule as a consequence of the privilege of limited liability.

Yet this important principle with respect to dividends was destined to be overturned by Lord Justice Lindley, who, in a series of decisions ${ }^{14}$ from 1889 in effect redefined the rules for capital maintenance, in the process overturning emerging accounting principles much to the consternation of accountants [Dicksee, (1892), pp.135-137]. But these legal decisions did not link coherent definitions of capital and profits. Following the precedent from partnership law, the courts regarded the determination of profits, provided there was no evidence of fraud, as a matter of internal management to be decided by majority 
decision of members, or directors, in accordance with the articles [Johnston et al., (1983), p.127].

However, dividend distributions were still required, and a definition of capital implies a definition of profit. Yamey (1962a, p.41) wrote: "It was the accounting conventions and not the legal requirements that in practice imposed the real restraints on the calculation of divisible profits"15. At a time when the profession was emerging, the legal decisions blunted its authority, not only throwing accountants into disarray, but also weakening their position with directors. The directors no doubt noted the freedom accorded them provided they acted honestly. Hence, the stage was set for men of business to create secret reserves for the purposes of dividend equalisation, and for these secret reserves to be lauded as the hallmark of a sound business [Edwards, (1976), p.297].

In evidence to the Company Law Amendment Committee (1926) chaired by W. Greene, the ICAEW advocated that "the question of accounts was best left to the directors" and that "it is impossible to protect fools from their folly" [Johnston et al., (1983), p.8]. Apparently the Law Society held similar views to the ICAEW [Edwards, (1976), p.290]. These views prevailed and the report of the Greene Committee in 1926 recommended modest changes enacted in the Companies Act 1928, including publication of a profit and loss account and balance sheet.

Then came the 1931 Kylsant case. In de Paula's (1948a, p.35) classic phrase "the profession had gone on happily and satisfied that all was well, when suddenly, out of a blue sky, an atom bomb fell that shattered our self-complacency and startled and shocked the public". This was a case in which a great company, the Royal Mail and Steam Packet Company, had raised funds from the public and had paid dividends throughout the 1920s but had failed to disclose that from 1921 to 1929 it had not recorded a trading profit. Large profits made during and after the war, hidden in secret reserves, were transferred to profit and loss as required. For this deception a Lord of the Realm was sent to prison, while the auditor was apparently acquitted on a technicality ${ }^{16}$.

This resulted in an enormous change from the previous attitude of 'non-interference' of the ICAEW evident in their recommendations for extensive disclosure in accounts presented to the Committee on Company Law Amendment (1945). It was also referred to by the name of its chairman, Lord Justice Cohen. The commencement in 1942 of the issue of a series of recommendation on accounting principles by the Taxation and Financial Relations Committee of the ICAEW signalled the new, proactive approach. The sweeping changes recommended by the Cohen Committee were enacted in the Companies Act 1947, becoming on consolidation the Companies Act 1948. The use of secret reserves was outlawed; henceforth all movements in reserves were to be disclosed, and items appropriately classified. Both the balance sheet and the profit and loss account were required to give a "true and fair view", and to be audited. Consolidated accounts were introduced.

Although the Cohen Committee clearly favoured disclosure of fixed assets at their cost less accumulated depreciation, the description of the historical cost basis was incomplete in at least two respects. First, profit was not defined; and secondly, their recommendations, unwittingly it seems, included a general clause permitting the valuation of fixed assets, rather than valuation being restricted to the three exceptions referred to in the recommendations of the 1945 Cohen Committee (para. 100) ${ }^{17}$. Nevertheless, overall the amendments were welcomed.

In endorsing the historical cost basis of accounts outlined in the Cohen Committee Report, the 1962 Jenkins Committee noted that such accounts may need to be 
"accompanied by supplementary information in order to give shareholders the true and fair view required by the Act” (paragraph 334). The Committee endorsed the improved function of annual accounts from the evidence of the ICAEW, and, noting that the realisation concept had been virtually "universally applied", recommended that the same principle should be applied in determining capital profits (paragraph 337, quoted p.18). Further, paragraph 350 recommended several amendments necessary to clarify the unsatisfactory case law initiated by L.J. Lindley in 1889 but it was to be several years before they were enacted. After summarising the effect of the Companies Acts of 1980 and 1981 on the legal rules for calculating distributable profits, Edwards (1989, p.187) commented that the "overall effect is to give specific legal emphasis to the realisation and accrual concepts and general statutory support for the, more rigid, profit measurement procedures traditionally favoured by accountants". Thus, on both sides of the Atlantic, the system of historical cost accounting received strong support.

\subsection{Financial information needs}

Returning to the question of the relevant information needs, de Paula (1948b, p.422), writing after the enactment into UK company law of the recommendations of the 1945 Cohen Committee, summarised the purposes of annual accounts in this classic statement:

“...it is clear that the annual accounts of companies are purely domestic documents and represent the rendering by directors of an account of their stewardship. There are two main purposes, firstly to give to the proprietors a true and fair view of the company's revenue transactions and thus to show what profits (if any) are available for distribution, and secondly to give a true and fair view of the financial position of the company at the end of its financial year."

Developments ${ }^{18}$ since appear to have obscured this simple and clear objective which retains its relevance today (Lennard, 2007).

The users assumed are the ordinary shareholders of a company. The first information need recognised is for financial information enabling assessment of whether the paid in money capital has been maintained, and the related question of whether monetary profit is a genuine surplus over the money capital (plus any retained monetary profits at the beginning of the current period). The purpose of the legal rule limiting dividends to profits is to ensure that creditors are not defrauded through the return to shareholders of their paid in money capital under the guise of a dividend. The claims of creditors are debts expressed as a sum of money, and settlement of their debts takes precedence over payments to the shareholders. Assuming that monetary profit is a genuine increase over money capital, and that dividends do not exceed monetary profit, then the amount of the money capital will not be distributed as a dividend, and hence creditors will receive the protection intended by the law.

The second information need recognised in the monetary interpretation is for the directors to provide a report of stewardship to the shareholders for the actual use they have made of the money capital invested in the firm, and the actual results achieved from using that money capital. Both of these purposes are rooted in ownership - there is no profit without an increase in assets arising from executed contracts. Further, profit also implies an excess of money revenue inflows over money cost outflows, a complementary measurement ensuring that profit represents an increase over the money amount of the invested capital. The more detailed explanation which follows explains the accounting 
principles in terms of the transactions arising from executed contracts which change property rights. Measurement of monetary profit applies the accounting principles of realisation and cost allocation, the latter including the recoverable cost rule.

\subsection{Revenue measurement}

Revenue arises, or comes into existence, from a completed sales contract under which goods or services are exchanged for the monetary consideration stipulated in the executed sales contract. This is known as the realisation concept. Coombes and Martin (1982, p.13) described the US case, Eisner v. Macomber, 25 U.S. 188 (1920) as "[p]erhaps the most noted case in the development of the realization principle". The Court "defined income not as 'a growth, but a gain, a profit, something of exchangeable value proceeding from the property, severed from the capital'”. The concept of a change in property rights through a market transaction (exchangeable value, severed from the capital) is captured in this judgment. However, the clarity of this judgment has not been reflected in accounting theory or the conceptual frameworks of professional bodies.

The members of the American Institute of Accountants voted in 1934 to endorse five principles of accounting, the first of which included the sentence reading:

\footnotetext{
"Profit is deemed to be realized when a sale in the ordinary course of business is effected, unless the circumstances are such that the collection of the sales price is not reasonably assured."
}

The five principles had been formulated by the Special Committee on Co-operation with Stock Exchanges, chaired by George O. May, and established about 1932 by the then American Institute of Accountants (Storey and Storey, 1998). Undoubtably, May would have been a strong influence in the Special Committee. Indeed, May (1950, p.263) included the realisation concept as one of "... the three most fundamental postulates of accounting"19, describing it in these terms:

1 that the entire income from sale arises at the moment when realisation is deemed to take place.

Similarly to the definition of the American Institute, vagueness is introduced by the expression "when realization is deemed to take place".

In addition, May (1943b, p.22) allowed interest to confuse the picture, arguing that the "most theoretically correct concept of the income account is that charges or credits to it accrue from day to day, and this concept is applied whenever practicable - as in the case of rent and interest”. However, normally both interest and rent are stipulated at a rate or amount according to time in the contract giving rise to them. Thus, it is the contract rather than the "theoretically correct concept of the income" which enables the accrual of interest and rent. In sharp contrast, however, "daily accrual" of revenue in respect of sales of goods or services would be inappropriate, except in the unlikely event it was provided for in the contract of sale.

Paton and Littleton (1940, pp.46-48) defined revenue as "the product of the enterprise, measured by the amount of the new assets received from customers". It is to be measured as the "price-aggregates (unit price times quantity) of a sales transaction and periodic revenue is expressed by the sum of the price-aggregates ...”. This description identifies the contract (sales transaction) and money consideration (price-aggregates) central to revenue - and the monetary explanation. Indeed, these authors by their 
emphasis of "measured consideration” and "price aggregates” came close to articulating the monetary concepts.

Across the Atlantic, the 1962 Jenkins Committee explicitly recognised that profit (revenue) depends upon ownership, and that the same concept is applicable to both socalled capital and revenue profits. The Committee wrote:

\begin{abstract}
"It is a fundamental principle or convention of accounting practice that profit is normally established at the point of time when it is realized by transfer of ownership or completion of the services rendered. It is possible to imagine an accountancy convention which required profits to be established at a later time, namely, when payment is made or at an earlier time, when a fair estimate can be made. It is, however, not necessary for us to consider these alternatives because in determining revenue profits the practice of establishing the profit at the time the ownership passes - has, with minor exceptions, been universally applied. ...This practice in the establishment of revenue works well and we think that, as far as is practicable, the same principle should be applied in ascertaining capital profits.” (paragraph 337)
\end{abstract}

Their conclusion that "the practice of establishing the profit at the time the ownership passes - has, with minor exceptions, been universally applied” stands in contrast to the criticism of the concept, and supports the similar conclusion of Vatter (1966).

In a surprising turn, the role of property rights in revenue recognition has received unexpected support from the IASB and the FASB in their joint Discussion paper of December 2008 titled Preliminary Views on Revenue Recognition in Contracts with Customers (IASB, 2008). The application of the core principle requires identifying contracts with customers and the separate performance obligations, determining the transaction price (contract consideration), allocating the price to the separate performance obligations and finally recognising revenue when the entity satisfies the performance obligation (IASB, 2010). Although expressed in new language, this is the realisation concept based on changes in property rights from executed contracts. As such it appears to be a radical departure from fair value with the potential to change the basis for revenue and asset measurement under international accounting standards.

\title{
4.4 Measurement of expenses
}

Expenses are the money costs of economic resources consumed in the production of goods and services. They also arise from executed contracts, in this case contracts providing for the supply of the economic services. Similarly, the money consideration stipulated in the relevant contracts provides the cost of acquisition of the particular economic services. The costs of economic services consumed in the period are treated as expenses of that period. The costs of economic resources which benefit more than one accounting period in the earning of revenue are apportioned to periods on the basis of services used. This is known as the cost allocation principle [AAA, (1936/1957), p.61].

Further, to ensure that, due to changing market conditions or expectations, no element of loss is hidden in the costs carried forward, these costs are compared with their recoverable cost. Recoverable cost is the higher of the future net revenue expected from an asset, or its net realisable value. Should the written down cost of an asset exceed its recoverable cost, then the excess of the net cost over recoverable cost is treated as an expense, and the asset written down accordingly ${ }^{20}$. The AAA (1936/1957, p.62) enunciated an overarching rule in these terms: 
"Every business enterprise should eliminate from its accounts those costs which are applicable to assets no longer useful or salable, and should reduce the carrying values of assets in use or ultimately to be marketed to such amounts as may reasonably be expected to be recoverable in the course of future operations."

In a critique of the AAA’s 1936 Tentative Statement, Rorem (1937, p.134) applauded:

"The most significant contribution to accounting valuation ... is the implicit recognition by the committee of the similarity of current and fixed assets. The rule of cost-less-depreciation for fixed assets is the same in principle as the rule of cost-or-market for current assets. Each of these values is an attempt to adjust the values to such amounts as may reasonably be expected to be recoverable in the course of future operations. But in each case the anchor-point of valuation is the original cost, and the changes are attempts to measure expired values.”

He also claimed that the committee had "given a better defence of the old dogma [conservatism], or if one prefers, has changed the dogma into a logically defensible rule" [my insert].

Two criticisms levelled at cost allocations are that they are arbitrary, and that they lack empirical reference. As previously noted, Thomas (1974) conceded that purpose based statements could escape his criticisms. The second criticism is, however, more difficult to answer as there is simply no empirical evidence available detailing the using up of services period by period from some joint costs. While their overall cost, and their expected economic life may be known, the periodic consumption of services can only be estimated, meaning that the amounts at which fixed assets are shown in the balance sheet are simply estimates of their 'unexpired costs', which are expected to be recovered out of future revenue.

It does, of course, need to be appreciated that every item in a balance sheet (of any model) has future reference, and that its realisation is more or less probable depending on its nature, and the prevailing circumstances. Nevertheless, the allocation can be explained using principles and experience. The allocation can be based on the principle of allocating the cost according to the services consumed, or expected to be consumed, using manufacturer's specifications, and past experience of similar assets or taxation records (Crumbley, 1978). Service consumption can be estimated with sufficient reliability for most fixed assets to be useful for periodic profit measurement. Using the relationship between fundamental measurements (transactions) and the measurements derived from them (profit, for example), measurement theory can provide support for the allocation of the cost of fixed assets based on services.

Fundamental measurements do not depend on any prior measurements whereas derived measurements take their meaning from the fundamental measurements [Hempel, (1952), p.58; Krantz et al., 1971]. Suppes and Zinnes (1965, p.17) also emphasised that derived measurement "does not depend on an empirical relation system directly but on other numerical assignments”. Hempel (1952, p.69) noted that derived measurement "does not introduce a 'new' quantity but rather an alternative way of measuring one that has previously been introduced ... by the discovery of some law which represents the magnitude in question as a mathematical function of other quantities for which methods of measurement have likewise been laid down previously". A similar view of the relationship is given by Kaplan (1964, p.187), derived measurement being "one which is carried out by making use of laws, logical or empirical, relating to fundamental measures". 
Applying this approach, the fundamental measurements provide the basic parameters for the net cost to be allocated using service consumption in accordance with the principles of the monetary model. Accepting that the particular services of each fixed asset are an intensive property which can be measured using the ratio scale (AbdelMagid, 1979), periodic depreciation expense can be calculated by multiplying the depreciable cost of the particular fixed asset by the ratio that the services used in the particular period bears to the total expected economic services of that asset. It will be appreciated that as an intensive property the particular service (kms. of transport, number of plates stamped, etc.) only applies to the particular non-monetary depreciable asset. Subject to the recoverable cost rule, the depreciable asset is measured in the balance sheet at cost less sums written off as expenses periodically. Hence, the principles of the monetary model are applied, with the fundamental measurements providing the basic parameters. Of course, as the future is uncertain, the estimates of future services, likely scrap value, and other assumptions require regular review.

An alternative favoured by several writers is to use probabilistic depreciation which they regarded as "theoretically more correct" [Ijiri and Kaplan, (1969), p.750]. Yet the judgement of 'theoretical correctness' depends on the objective of measurement assumed in each case. Brief and Owen (1970) sought a means to estimate the long run rate of return from the known period return, assuming measurement of the former to be the objective. Lane and Willett (1997) argued that depreciation calculated using a probabilistic stochastic model should improve the statistical property of earnings as an estimator of long run cash flow. In another variation on the rate of return theme, the Australian Accounting Research Foundation [AARF, (1998), p.1] postulated as the ideal formulation of the conventional accounting model, depreciation which "enables the entity to earn a constant after-tax rate of return on its investment in the asset". This appears similar to the so-called annuity method which assumes the asset earns the going rate of return, with depreciation calculated accordingly (Warrell, 1989), a throwback to a method Canning (1929b) rejected. However, with different objectives to those of periodic monetary profit measurement, none of these approaches utilises the allocation of cost based on the services consumed in particular periods.

Before concluding this section on cost allocation brief comments are offered on conservatism and its role, if any, in measuring periodic monetary profit. The adjective 'conservative' is given four meanings by the OCED (2003, p.227), two of which are not relevant as they relate to the political context, and a political party. The relevant definitions read " 1 averse to change and holding traditional values" and "4 (of an estimate) purposely low for the sake of caution”. Many business people critical of traditional accounting would agree with the first, general definition, their criticism reflecting their opinion that the historical cost basis is outdated and inadequate. That view would also be supported by accounting theorists advocating the use of current market prices throughout financial statements, for example Sterling (1967). Being 'adverse to change' may be a positive or negative factor, depending on the circumstances; likewise for 'holding traditional values'. A judgment would need to be made about the relevance of the particular values, and whether they were universal. The evaluation of these general criticisms thus needs to go beyond their generality, and to consider the merits of the system criticised and also of the alternative proposed. This more detailed approach in effect leads to consideration of the fourth OCED (2003) meaning of conservative.

Many traditional accountants, Gilman (1939) for example, have criticised the use of the lower of cost or market rule for measurement of merchandise inventories as 
inconsistent for taking into account price falls in inventory items while ignoring price rises. This rule may result in a measurement lower than cost, but never one exceeding cost, hence the description as conservative being "purposely low for the sake of caution". Now if the application of a particular accounting rule always resulted in this 'lower' outcome it could be described as conservative, and if like rules dominated accounting practice, Sterling's (1967) conclusion that conservatism is "the fundamental principle of accounting valuation" might be vindicated. The problem is that to consider only the impact on profit of the period in which the inventory is written down is to ignore half the story; the other half arises when the inventory item is sold. An example ${ }^{21}$ clarifies that it is impossible to be consistently 'conservative' in this 'deliberately lower' sense, as one period's conservatism becomes a later period's gain. Paton and Littleton (1940, p.128) appreciated this point, and its practical consequences.

\subsection{Summary of monetary profit measurement related to changes in net assets}

Thus, bringing these principles together, the transactions giving rise to the two streams of money flows, one of money revenue flowing in and the other of money expenses flowing out, have their origins in the executed contracts changing the entities holding of property rights. Monetary profit is the excess of the money revenue over monetary expenses. Abstracting from any changes in the money capital and drawings or dividends paid, monetary profit for a period may be characterised as an 'adjusted cash flow' based on actual transactions with external parties changing property rights, after allowing for appropriate leads and lags in the timing of receipt and payment of cash (Fisher, 1930; Canning, 1933; Nelson, 1942; Fitzgerald, 1949; Carson, 1965). Put another way for a company, monetary profit may be regarded as the best available estimate of the current monetary distributable surplus after maintaining paid-in (or contracted) money share capital.

In addition to the profit statement, shareholders will wish to receive a balance sheet disclosing the amount and form of assets and liabilities and shareholders' equity measured consistently with monetary profit. The assets ${ }^{22}$ comprising money, rights to money and money expenditure carried forward are measured at amounts reflecting their significance in the revenue earning (conversion) process. No attempt is made to measure them at current prices other than to ensure that the amounts at which they are stated do not include unrecoverable sums or losses. This balance sheet is a unique construction that only makes sense in the context of monetary profit measurement.

This system may be described as a 'number-of-dollars measurement system' in which each dollar of cash flow, irrespective of when incurred, counts as one. These unique concepts of capital and profit are clearly distinguishable from other concepts like money income and current operating profit, and their 'real' counterparts, listed by Parker and Harcourt (1969, pp.4-16) in addition to accounting profit. Moreover, money income, which Hicks (1946, p.179) claimed was almost "completely objective" differs from monetary profit by including assets at their current market values. These authors also drew attention to the definition of personal income of Simons $(1938$, p.68) which was based on the "value of a person's store of property rights" and changes in them. Figure 1 summarises the relationship between the information needs and the measurements derived from them for monetary profit measurement. 
Figure 1 The relationship between the two information needs recognised and measurement of monetary profit and money capital

Shareholders' common information needs Measurement of monetary profits available for dividends, and of money capital maintenance Stewardship of the contributed money capital $\downarrow$

Qualitative, empirical property Changes in property rights

Specific properties of property rights Right(s) of use for profit $\downarrow$

Interpretation of the accounting elements

Owners' equity: money capital, retained monetary profits Assets: money, rights to money, and money expenditure (net) Liabilities: debts

Monetary profit $=$ revenue - expenses

(related meanings for changes in A, L and OE elements)

\section{$\downarrow$}

Accountingpolicies

Realisation, cost allocation including recoverable cost

Money (the domestic currency) as the unit of account

(plus detailed accounting policies, for example, depreciation)

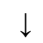

Circumstances

Opening balance sheet

Transactions for the period

Continuity condition, if applicable

$\downarrow$

Measurements reported in financial statements

Profit statement, showing monetary profit for the period

Retained profits statement for the period

Cash flow statement for the period

Balance sheet at period end

These principles for monetary profit measurement are demonstrated in an example shown in Appendix B, Part I, using the information included in the comprehensive business reporting model of the CFA Institute Centre for Financial Market Integrity (2007). A statement, reconciling the changes in net assets using IFRSs with monetary profit for $20 \times 4$, highlights the differences in current practice. Lease amortisation and interest of $€ 8,322$ is replaced by a proportionate share (75\%) of the annual rent, €7,500; deferred income tax of $€ 33,120$ is eliminated; revaluations of buildings and marketable securities totalling $€ 171,100$ are reversed; similarly for the equitable share in the earnings of an affiliate company. The net effect is to reduce the increase in the net assets available to common shareholders in 20x4 from €378,801 to monetary profit for the year of €229,393. These adjustments eliminate entries not supported by changes in property rights. 


\section{Wealth measurement}

The case for measurement and disclosure of the wealth of a company is now explained from a specific information needs perspective using relevant concepts from measurement theory. The two information needs recognised for wealth measurement are debt paying potential, and calculation of net exchangeable asset backing per ordinary share. Other needs may be equally relevant. If assets are to be used for paying debts they must be capable of being converted into cash. Liquidity is the name usually given to the funds available for payment of debts in the short term, while solvency refers to their long term counterpart. As this information need is now 'generally accepted' it is not discussed further here. The second information need is for calculation of net exchangeable ${ }^{23}$ asset backing per ordinary share. Basing the calculation of asset backing on the current market prices of the assets and liabilities enables comparison with the current share price. By showing the potential 'break-up' value of the company it can be particularly useful to shareholders in evaluating a takeover offer.

Stock exchanges operate on the basis that the share market is an informed market; that is, that buyers and sellers are able to ascertain all relevant information so that no one buyer or seller can obtain an unfair advantage in trading. Accordingly, strict rules for disclosure of market sensitive information have been stipulated. In spite of these provisions, many shareholders have learnt, subsequent to the sale of their shares, that they have sold them for an amount significantly less than the asset backing calculated using the net realisable value of the company's assets. Sometimes this may be no more than bad luck or bad timing of the seller.

However, where shareholders were not informed of relevant information, like the current market selling prices of major assets, known to the company but not reported to the shareholders, they will have a justifiable sense of grievance. Numerous examples exist of takeovers where the acquirer subsequently disposed of the assets, pocketing a large profit. Small shareholders are the more likely to be disadvantaged by non-disclosure of the realisable value of the company's assets simply because the large shareholders and institutional investors are in a much stronger position to ascertain relevant information.

Current cash equivalents (CCEs) ${ }^{24}$ of the net exchangeable assets are not disclosed as a matter of course in financial statements, and presumably their non-disclosure has been one of the forces behind the pressure for periodic revaluations, and, more recently, for the extended use of fair values. However, disclosure of periodic revaluations of some assets from time to time is not an adequate response, especially as the revaluations are often arbitrary. What is needed is annual disclosure of the current market selling prices of all exchangeable assets in a separate statement as a matter of normal reporting practice. Intangible assets, which can be separately sold, such as patents and trademarks, should be included.

As this is not a valuation of the business, but a schedule listing all the exchangeable assets and liabilities at their individual market prices, it is not appropriate to include general business goodwill. Further, it is not suggested that sensitive competitive information should be disclosed; but rather that information which in many cases would be a matter of public record should be disclosed. For example, government valuations of land and buildings, and prices from second hand markets of motor vehicles. For completeness, including comparison with the HCA balance sheet, specialised equipment, or assets for which there were no current prices, could be included at zero, or the fact simply reported that they had no separate market price. 
It is clear that the satisfaction of the two information needs recognised requires disclosure of the current market prices of all assets and liabilities where these are available. The right of sale of assets is the specific property right relevant in respect of these two information needs. Unless the company actually owns the asset, and holds the right to sell it at the balance sheet date, it is not in a position to sell it and receive the proceeds of sale. Valuation and inclusion in a schedule of wealth assumes that the company holds the current right of sale. Leased property unavailable for sale or for which no rights to sub-lease are held, and future income tax benefits are examples of assets which should not be included as no right of sale is held in respect of them. Accepting that the term wealth denotes measurement in current market prices, wealth provides the qualitative, empirical property under this interpretation.

Similarly, liabilities involve the negative property right - the obligation to settle debts - in accordance with the contract for value received or the levy or charge imposed by a lawful authority. The entry in the wealth schedule will be the current market settling price plus any transaction costs. Deferred income tax is an example of a liability that does not constitute an actual obligation evidenced by property rights, and it should not be included. Thus the right of sale coupled with the obligation to settle derived from these information needs calls for measurement of assets and liabilities at their CCEs, and in total, the entity's net wealth. This sum, divided by the relevant number of ordinary shares, yields the amount of net asset backing per ordinary share. These relationships are shown in Figure 2.

Figure 2 The relationship between the two information needs recognised and the measurement of wealth

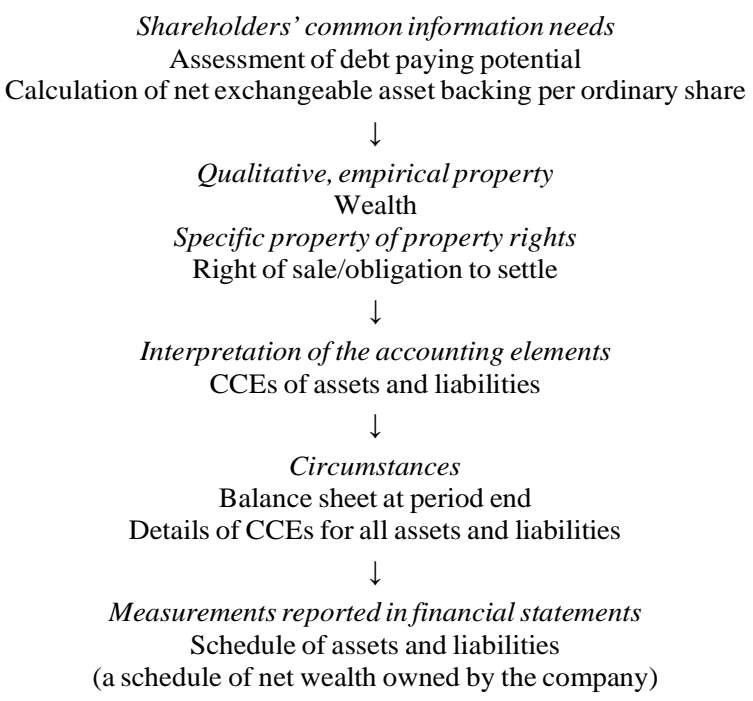

Wealth, a net concept, provides the qualitative, empirical property, in respect of these two information needs. It is measured as the sum of the CCEs of all assets, less the settling price of all liabilities, as explained above. The question then is whether measurement theory offers support for the measurement of assets and liabilities at their CCEs. Initially, Chambers (1966, p.91) thought that, defining CCEs as the numerosity of the number of 
dollars, enabled them to be measured using the absolute scale. However, this was disputed, Vickrey (1975, p.67) pointing out that the absolute scale requires the identity of the property being measured to be maintained. Under Chambers (1966) system, purchasing power as the object of measurement, constitutes his qualitative, empirical property. While it is arguable that the current dollars in which CCEs are expressed represent current purchasing power, the identity of the non-monetary assets is clearly not maintained when viewed as purchasing power. On this ground, they do not qualify for measurement using the restrictive absolute scale.

However, accepting that CCEs are a valid property of assets and liabilities that can be used to measure wealth, measurement theory criteria may be able to be met, subject to a caveat in respect of the qualitative, empirical property. Strictly speaking, the market value of a non-monetary asset held by an entity does not constitute an actual measurement of the particular asset - it is the empirical measurement of another, similar asset which has been traded in the market. This weakness may be mitigated using the measurement theory concept of derived measurement in a way similar to its use in explaining cost allocations. The transaction arising from the executed contract of purchase (the fundamental measurement) secures the ownership of the asset, including the right of sale. Apart from sale and thus liquidation of the asset (presumably contrary to the company's intention), there is no foreseeable way to obtain an empirical measurement of its market value. Perhaps it is arguable that the measurement of the 'similar asset' is a derived measurement, 'derived' by virtue of the ownership of a like asset, which otherwise satisfies the principles established for measurement of CCEs.

In the event that a collective judgment is made by accountants that CCEs cannot satisfy measurement theory criteria, then the less stringent conditions postulated by Vickrey (1970, p.738) provide an alternative. He advocated three conditions as necessary and sufficient for the recognition of financial accounting as measurement. Basically, he sought an extensive economic property which

1 is possessed by accounting phenomena

2 is measurable in standard monetary units

3 is accepted by accountants as appropriate for accounting measurements.

Measurement of wealth using CCEs, and disclosed in a separate schedule independent of profit measurement, should satisfy these conditions.

General support for disclosure of the CCEs as a measurement of wealth exists (Bromwich and Wells, 1983; Stamp, 1983; Williams, 2003). Indeed, empirical surveys by Chambers (1980) and Chambers et al. (1987) offer strong support for disclosure of wealth. More recently, the hearings conducted by the SEC in 2008 on mark to market accounting also provided strong support for their disclosure.

\section{Concluding comments}

Monetary profit measurement has been explained as a coherent and logical system to deliver relevant financial information to shareholders in relation to the two information needs conventionally referred to as money capital maintenance, and stewardship of the paid in money share capital. The initial design may be described as 'top down' in the sense that the general accounting system (before application) is based on the fundamental 
relationships of the accounting elements, represented formally in the DEC. Its strength is the logical relationships secured among the accounting elements for the measurement of capital and profit. The system is anchored in reality through transactions, the fundamental measurements which measure the change in property rights. The basic axiom equates the change in owners' equity with the change in net assets, the primitives of the system.

The general system, following its interpretation and application for monetary profit measurement, has the potential of a sound theory, the significance of which is best demonstrated by the realisation principle, the most distinguished and emphatic principle due to its direct and clear relationship to changes in property rights. This principle captures the time point when property rights are changed for both parties on execution of the sales contract. In contrast to the cloud of uncertainty frequently obscuring the evidence of 'service expiry' required by the cost allocation principle, contracts can be written to accommodate a range of different types of sales. Overall, the transaction based fundamental measurements including periodic cost allocation for monetary profit measurement (supported as derived measurements), can satisfy measurement theory criteria.

The general system perforce requires a method for its interpretation. Postulate 4 shows how specific meaning can be conferred on assets, liabilities and owners' equity from the recognised information needs of shareholders, thereby securing financial information relevant to those needs. The specific concept of property rights derived from money capital maintenance and stewardship of the money funds is the 'right(s) of use for profit'. These property rights constitute the qualitative, empirical property applying to all the accounting elements. For many transactions their application is straightforward, but as witnessed in the GFC (Kothari and Lester, 2012), application for complex, derivative-based contracts for which the precise meaning may not be clear can prove difficult. The broadness and inclusive nature of 'right(s) of use for profit' can render it complex.

Writers who have supported the notion that different purposes call for different measurement systems include Bonbright (1937), May (1943a), de Paula (1948b), Johnston (1949), Edey (1962), Carrington (1964), Mattessich (1964a, 1972), Carsberg et al. (1974), Accounting Standards Steering Committee (1975), Barton (1982), Kennedy (1986) and Parker et al. (1986). Moreover, noted economists including Canning (1929b), Fisher (1930), Hayek (1941), Hicks (1942) [also see Brief (1982) on Hicks], Alexander (1950), Kaldor (1955) and Boulding (1962) have supported transactions-based accounting as being satisfactory for the traditional purposes assumed (de Paula, 1948b). With the advent of conceptual frameworks, professional bodies have preferred the general purpose approach.

The output of the monetary model, this first interpretation derived from the general accounting system, is then compared to the reality of accounting practice, and the reasons for its support, over the decades of the 1940s to 1960s when historical cost flourished ${ }^{25}$. The monetary explanation can provide the missing pieces required for a full explanation of profit measurement, and it supports the majority of the applications during that period. In this context, the exceptions were for the items unsupported by property rights, notably equity accounting, tax allocation and leasing. Perhaps leasing is the most controversial of these items for periodic profit measurement. Under the monetary interpretation, the 'hypothetical purchase and loan' applied in accounting standards is replaced by the contract right of annual use subject to payment of the contractual annual rental (plus any 
other charges); in contrast, the lease does not appear in the wealth statement as no 'right of sale' is held in respect of it.

The review of the works of the major writers and bodies on accounting over the three decades of the 1940s through the 1960s in Britain and the USA found that 'transactions-based' accounting dominated, with revenue recognition and cost allocation principles being generally accepted and applied (May, 1950; Vatter, 1966). Thus, apart from the several exceptions mentioned, conventional profit measurement largely accorded with the principles of the monetary model. The virtually unanimous agreement on all matters of substance, including the cost basis, of the early committee members of the AAA (about 12 men) responsible for drafting the 1936 Tentative Statement, and subsequent amendments (Zeff, 1966), was remarkable. Their work was continued in the Paton and Littleton (1940) monograph, which achieved fame "as the most influential monograph in U.S. accounting literature” [Zeff, (1999), p.90]. But "price aggregates” and "measured consideration" was as close as Paton and Littleton (1940, p.12) got to contracts, and changes in property rights.

The change in attitude of accountants in Great Britain attributed to the Kylsant case was reflected in a clear and forthright manner in the evidence endorsing the historical cost basis of the Institute of Chartered Accountants in England and Wales (ICAEW) to the 1945 Cohen Committee, and enacted into law in 1947. In 1952, the Institute first used the expression "monetary profits" (ICAEW, N15, 1952), to describe profits computed under historical cost, and later in evidence to the 1962 Jenkins Committee. This committee expressly recognised the significance of "ownership passing" for revenue recognition, and recommended the same approach for capital profits.

Assuming property rights can provide a coherent explanation for monetary profit measurement over the decades of the 1940s through the 1960s, the question posed here is why that basis has not been generally recognised. The 1920 ruling from the US Supreme Court established realisation as a central, legal concept. Further, endorsement in 1934 by the members of the American Institute confirmed its core status, later also endorsed by the UK 1962 Jenkins Committee. Perhaps it was expecting too much that accountants would follow Fisher's (1906) clear lead on the nature of assets and liabilities, an issue still unresolved today. Cushing (1989) and Archer (1993) drew attention to the shift accompanying professional standard setting from accounting theory to related areas. The abuse of historical cost accounting by the regulators and others during the Savings and Loans Crisis (Young, 1995) enabled entrepreneurs like Skilling of Enron fame to favour mark to market accounting as reflecting the "true economic value" [Mclean and Elkind, (2003), p.40]. Accountants as a group remain enamoured with the views of neoclassical economists.

Paton and Littleton (1940) were lured from their accounting objective in favour of an economic one. The ambivalence of May (1950) on realisation, who sought an economic rather than a legal concept impeded progress. The clear statement of the AAA $(1936 / 1957)$ on the recoverable cost rule did not become accepted theory. And in the UK, de Paula's (1948a) explanation of going concern valuation, diluted under cross examination to cost less depreciation, lacked conviction. Thus, in spite of Vatter's (1966) opinion that realisation and cost allocation were well entrenched in professional practice, that position was not reflected in accounting theory. Nevertheless, a full understanding now of monetary profit measurement should enable theorists to re-evaluate the concept in the light of today's conditions. It is a dynamic concept that can immediately incorporate 
innovations in the writing of contracts into accounting, assuming that they are properly understood.

The second interpretation of the general accounting system supported measurement of wealth for the information needs of calculating debt paying potential and the net exchangeable asset backing per ordinary share. The 'right of sale', selected from those two information needs, is the relevant property right for the measurement of wealth. The demand for a separate statement measuring the wealth of an accounting entity has been overlooked for too long, and the present hybrid balance sheet is a poor substitute. Under the dual reporting systems explained, the balance sheet of the monetary model is cost based while the separate statement of wealth shows assets and liabilities at their current prices. This dual, specific purpose, approach effectively answers the criticism of Parker (1965, p.172) that "accountants cannot have it both ways: either the balance sheet is a historical record or it is a statement of current resources". The balance sheet of the monetary model can be described as an historical record, while the wealth statement is a statement of current resources available for sale. Each internally consistent set of measurements satisfies different information needs; moreover, each set complements the other.

The measurement of liquidity disclosed in the wealth schedule provides information relevant for evaluating the continuity assumption required for monetary profit measurement, while the balance sheet of the monetary model provides cost-based information on the remaining investment commitment in property, plant and equipment. Thus, the two approaches together provide a more complete view of assets and liabilities. Future uncertainty, however, offers a caution - all amounts shown for assets in a balance sheet (of any model) or a statement of wealth, depend on future expectations and their realisation, factors which are more or less probable depending on the nature of the assets and the prevailing economic circumstances.

Property rights are gaining recognition in economic theory, particularly the NIE. Together with Post Keynsian economics, they more fully explain the institutional environment in which accounting operates, and thus assist in elucidating its concepts. Under this rubric, research into governance issues appears to have grown, but with accounting thinking still dominated by neo-classical economics, North (2005) suggests change in these assumptions may be a long time coming. Other areas of research suggested by the NIE, and recent events, are developments in contracts, particularly in the relatively new areas of derivatives.

It will be recalled that Alexander (1950, p.2) believed that income measurement could be reduced to three main issues: first, the real versus the money measure; second, inclusion or exclusion of capital gains; and third, accrual versus realisation. For monetary profit measurement, the money measure is relevant for money capital maintenance rather than a 'real measure'; capital gains are included as realised; and realisation, due to its direct association with changes in property rights, is preferred to accrual for the timing of gains and losses. Accrual is, however, a concept applied under the monetary model to the measurement of periodic expenses based on service expiry, subject to the recoverable cost principle.

To conclude, a brief comment is offered on the financial statements prepared as examples of the application of these two interpretations of the general accounting system, and shown in Appendix B. Each of the two measurement systems 'faithfully represents' the relevant property rights or changes in them, and the financial statements disclose a 'true and fair view' of that information in relation to the information needs. A 
reconciliation statement highlights the differences in asset measurement, with the unrealised gains included in the measurement of wealth exceeding monetary profit for 20x4 almost threefold. The temptation to label the balance sheet of the monetary model as 'conservative' on this ground, however, should be resisted as this kind of difference, normal in the upswing stage of the trade cycle, can reverse in the downswing. It will be observed that, as a hybrid reflecting IFRSs, the total amount for assets shown in the balance sheet of Trans-Global at 31 December 20x4 lies between those in the balance sheet of the monetary model and the wealth statement.

\section{Acknowledgements}

The author would like to thank colleagues at the University of Western Sydney, and at the University of Wollongong, for their comments and support. Also, special thanks are due to Professor Garry Tibbits, UWS, for insightful comments and suggestions.

\section{References}

Abdel-Magid, M.F. (1979) 'General-price-level-adjusted historical-cost statements and the ratio-scale view: a comment’, The Accounting Review, Vol. 54, No. 4, pp.825-829.

Accounting Standards Steering Committee (1975) The Corporate Report, A discussion paper published for comment, London, UK.

Alexander, S.S. (1950) 'Income measurement in a dynamic economy', Monograph in Alexander, S.S., Bronfenbrenner, M., Fabricant, S. and Warburton, C. (1950/1973): Five Monographs on Business Income, pp.1-95, Scholars Book Co., Lawrence, Kansas.

American Accounting Association (AAA) (1936/1957) 'A tentative statement of accounting principles underlying corporate financial statements', The Accounting Review, June, reprinted in Accounting and Reporting Standards for Corporate Financial Statements and Preceding Statements and Supplements, University of Iowa, Iowa.

American Accounting Association Financial Accounting Standards Committee (AAA FASC) (2012) 'Some conceptual tensions in financial reporting', Accounting Horizons, Vol. 26, No. 1, pp.125-133.

American Institute of Certified Public Accountants (AICPA) (1958) 'Report to council of the special committee on the research program', The Journal of Accountancy, Vol. 106, No. 6, pp.62-68.

American Institute of Certified Public Accountants (AICPA) (1973) Objectives of Financial Statements, Report of the Study Group (known after its Chairman as the Trueblood Study Group), New York.

Andrews, P.W.S. (1949) Manufacturing Business, Macmillan, London.

Archer, S. (1993) 'On the methodology of constructing a conceptual framework for financial accounting', Chapter 5 in Mumford, M.J. and Peasnell, K.V. (Eds.): Philosophical Perspectives on Accounting, Essays in Honour of Edward Stamp, pp.62-122, Routledge, London.

Archer, S. (1998) 'Mattessich’s critique of accounting: a review article', Accounting and Business Research, Vol. 28, No. 3, pp.297-316.

Australian Accounting Research Foundation (AARF) (1998) Measurement in Financial Accounting, Accounting Theory Monograph No. 10, Melbourne.

Barth, M.E. (2007) 'Standard-setting measurement issues and the relevance of research', Accounting and Business Research Special Issue: International Accounting Policy Forum, pp.7-15. 
Barton, A.D. (1974) 'Expectations and achievements in income theory', The Accounting Review, Vol. 49, No. 4, pp.664-681.

Barton, A.D. (1982) Objectives and Basic Concepts of Accounting, Accounting Theory Monograph No. 2, AARF, Melbourne.

Berg, B.L. (1998) Qualitative Research Methods for the Social Sciences, 3rd ed., Allyn and Bacon, Boston.

Bierman Jr., H. (1963) 'Measurement and accounting', The Accounting Review, Vol. 38, No. 3, pp.501-507.

Bonbright, J.C. (1937) The Valuation of Property, McGraw-Hill, New York.

Boulding, K.E. (1962) 'Economics and accounting: the uncongenial twins', in Baxter, W.T. and Davidson, S. (Eds.): Studies in Accounting Theory, pp.44-55, Sweet and Maxwell Ltd, London.

Brief, R.P. (1982) 'Hicks on accounting', The Accounting Historians Journal, Vol. 9, No. 1, pp.91-101.

Brief, R.P. and Owen, J. (1970) 'The estimation problem in financial accounting', Journal of Accounting Research, Vol. 8, pp.167-177.

Bromwich, M. and Wells, M.C. (1983) 'The usefulness of a measure of wealth', Abacus, Vol. 19, No. 2, pp.119-129.

Canning, J.B. (1929a) 'Some divergences of accounting theory from economic theory', The Accounting Review, Vol. 4, No. 1, pp.1-8.

Canning, J.B. (1929b) The Economics of Accountancy, The Ronald Press Company, Reprinted 1978, Arno Press, New York.

Canning, J.B. (1933) 'A certain erratic tendency in accountants' income procedure', Econometrica, Vol. 1, No. 1, pp.52-62.

Carrington, A.S. (1964) 'Certainty' or Realism in Accounting, Invitation Lecture, N.Z. Society of Accountants, Wellington.

Carsberg, B., Hope, A. and Scapens, R.W. (1974) 'Objectives and functions of published accounting reports', Accounting and Business Research, Summer (1974), reprinted in Parker, R.H. (Ed.) (1978): Readings in Accounting and Business Research 1970-1977, pp.5-16, The Institute of Chartered Accountants in England and Wales, London.

Carson, A.B. (1965) 'Cash movement: the heart of income measurement', The Accounting Review, Vol. 40, No. 2, pp.334-337.

CFA Institute Centre for Financial Market Integrity (2007) A Comprehensive Business Reporting Model Financial Reporting for Investors, Charlottesville, USA; Hong Kong; and London.

Chambers, R.J. (1955) 'Blueprint for a theory of accounting', Accounting Research, UK, Vol. 3, No. 1, Reprinted 1969 in Accounting, Finance and Management, pp.347-364, Butterworths, Sydney.

Chambers, R.J. (1957) 'Detail for a blueprint', The Accounting Review, Vol. 32, No. 2, Reprinted 1969 in Accounting, Finance and Management, pp.365-371, Butterworths, Sydney.

Chambers, R.J. (1960) 'The conditions of research in accounting', The Journal of Accountancy, Vol. 110, Reprinted 1969 in Accounting, Finance and Management, pp.347-364, Butterworths, Sydney.

Chambers, R.J. (1963) 'Why bother with postulates?', Journal of Accounting Research, Vol. 1, No. 1, Reprinted 1969 in Accounting, Finance and Management, pp.384-395, Butterworths, Sydney.

Chambers, R.J. (1965) 'Measurement in accounting', Journal of Accounting Research, Vol. 3, No. 1, pp.32-62, Reprinted 1969 in Accounting, Finance and Management, pp.554-582, Butterworths, Sydney.

Chambers, R.J. (1966) Accounting, Evaluation and Economic Behaviour, Prentice-Hall, New York.

Chambers, R.J. (1980) The Design of Accounting Systems, The University of Sydney Accounting Research Centre, Sydney. 
Chambers, R.J., Ma, R., Hopkins, R. and Kasiraja, N. (1987) Financial Information and Decision Making: A Singapore Survey, Singapore Institute of Management Research Monograph No. 2, The Singapore Institute of Management and the University of Sydney Accounting Research Centre, Sydney.

Coase, R.H. (1937) ‘The nature of the firm', Economica IV, pp.386-405.

Coase, R.H. (1959) 'The federal communications commission', The Journal of Law and Economics, Vol. II, pp.1-40.

Coase, R.H. (1960) 'The problem of social cost', Journal of Law and Economics, Vol. III, pp.1-44.

Coase, R.H. (1992) 'The institutional structure of production', American Economic Review, Vol. 82, No. 4, pp.713-719.

Committee on Company Law Amendment (1945) Report of the Committee on Company Law Amendment, Cmnd.6659 (Cohen Committee), HMSO, London.

Company Law Amendment Committee (1926) Report of the Committee on Company Law Amendment, Cmnd. 2657 (Greene Committee), HMSO, London.

Company Law Committee (1962) Report of the Company Law Committee, Cmnd. 1749 (Jenkins Committee), HMSO, London.

Coombes, R.J. and Martin, C.A. (1982) The Definition and Recognition of Revenue, Accounting Theory Monograph No. 3, AARF, Melbourne.

Crumbley, D.L. (1978) 'Income taxation and its impact on financial reporting: an historical overview', in Merino, B. (Ed.): The Impact of Accounting Regulation Upon Accounting Theory, New York University, New York.

Cushing, B.E. (1989) 'A Kuhnian interpretation of the historical evolution of accounting', The Accounting Historians Journal, Vol. 16, No. 2, pp.1-41.

Davidson, P. (1972) Money and the Real World, Macmillan, New York.

Davidson, P. (1981) 'Post Keynsian economics: solving the crisis in economic theory', Chapter 10 in Bell, D. and Kristol, I. (Eds.): The Crisis in Economic Theory, pp.151-173, Basic Books, New York.

de Paula, F.R.M. (1948a) Developments in Accounting, Sir Isaac Pitman and Sons Ltd., London, Reprinted 1978, Arno Press, New York.

de Paula, F.R.M. (1948b) 'The effects of rising prices upon the capital requirements of a business', The Accountant, 5 June, Vol. 118, No. 3833, pp.421-423.

Demsetz, H. (1967) 'Towards a theory of property rights', American Economic Review, Vol. 57, No. 2, pp.347-359.

Demsetz, H. (1995) The Economics of the Business Firm Seven Critical Commentaries, Cambridge University Press, New York.

Dicksee, L.R. (1892) Auditing: A Practical Manual for Auditors, Gee and Co., London, Reprinted in 1976 by Arno Press, New York.

Edey, H.C. (1962) 'Income and the valuation of stock-in-trade', British Tax Review, pp.164-172, reprinted in Parker, R.H. and Harcourt, G.C. (Eds.) (1969) Readings in the Concept and Measurement of Income, pp.230-238, Cambridge University Press, Cambridge.

Edwards, E.O. and Bell, P.W. (1961) The Theory and Measurement of Business Income, University of California Press, California.

Edwards, J.R. (1976) 'The accountancy profession and disclosure in published reports, 1925-1935', Accounting and Business Research, Autumn, Vol. 6, No. 24, pp.289-303.

Edwards, J.R. (1989) A History of Financial Accounting, Routledge, London.

Edwards, R.S. (1938) 'The nature and measurement of income - I', The Accountant, 2 July 1938, pp.13-15, the full series of 13 articles reprinted in Baxter, W.T. and Davidson, S. (Eds.) (1962) Studies in Accounting Theory, pp.70-125, Sweet and Maxwell Ltd, London.

Fisher, I. (1906) The Nature of Capital and Income, reprinted in 1965 by Economic Classics, Augustus M. Kelley, New York. 
Fisher, I. (1930) 'The economics of accountancy', The American Economic Review, Vol. 20, reprinted as Chapter 2 in Parker, R.H., Harcourt, G.C. and Whittington, G. (Eds.) (1986) Readings in the Concept and Measurement of Income, 2nd ed., pp.66-81, Philip Allan, Oxford.

Fitzgerald, A.A. (1949) 'Inherent limitations of accounting', Paper presented at the 27th Meeting of the Australia and New Zealand Association for the Advancement of Science, January 1949, and reprinted in Fitzgerald, A.A. (1952) Current Accounting Trends, Butterworths, Sydney.

Folsom, E.G. (1873) The Logic of Accounts; A New Exposition of the Theory and Practice of Double-entry Bookkeeping, based in Value, as being Two Primary Classes Commercial and Ideal; and Reducing All their Exchanges to Nine Equations and Thirteen Results, A.S. Barnes and Company, Albany, New York, reprinted 1976, Arno Press, New York.

Frankel, S.H. (1949) 'Psychic' and 'accounting' concepts of income and welfare', Econometrica, July 1949, XVII Supplement, reprinted as Chapter 5 in Parker, R.H. and Harcourt, G.C. (Eds.) (1969) Readings in the Concept \& Measurement of Income, pp.83-105, University Press, Cambridge.

French, E.A. (1977) 'The evolution of the dividend law of England', in Baxter, W.T. and Davidson, S. (Eds.): Studies in Accounting, pp.306-331, The Institute of Chartered Accountants in England and Wales, London.

Furubotn, E.G. and Pejovich, S. (1972) 'Property rights and economic theory: a survey of recent literature', Journal of Economic Literature, Vol. 10, No. 4, pp.1137-1162.

Gaffikin, M.J.R. (1988) 'Legacy of the golden age: recent developments in the methodology of accounting', Abacus, Vol. 24, No. 1, pp.16-36.

Gilman, S. (1939) Accounting Concepts of Profit, Ronald Press Co Ltd, New York.

Gower, L.C.B. (1969) The Principles of Modern Company Law, 3rd ed., Stevens \& Sons, London.

Grady, P. (Ed.) (1962) Memoirs and Accounting Thought of George O. May, The Ronald Press Company, New York.

Hart, O.D. (1993) 'Incomplete contracts and the theory of the firm', Chapter 9 in Williamson, O.E. and Winter, S.G. (Eds.): The Nature of the Firm, Oxford University Press, Oxford.

Hastings, P. (1962) 'The case of the royal mail', Chapter in Baxter, W.T. and Davidson, S. (Eds.): Studies in Accounting Theory, pp.452-461, Sweet and Maxwell Ltd, London.

Hayek, F.A. (1941) 'Maintaining capital intact: a reply', Economica, Vol. 8, reprinted in Parker, R.H. and Harcourt, G.C. (Eds.) (1969) Readings in the Concept \& Measurement of Income, pp.127-131, University Press, Cambridge.

Hempel, C.G. (1952) 'Fundamentals of concept formation in empirical science', International Encyclopedia of Unified Science, Vol. 2, No. 7, p.iii, 93pp., The University of Chicago Press.

Hicks, J.R. (1942) 'Maintaining capital intact: a further suggestion', Economica, Vol. 9, reprinted in Parker, R.H. and Harcourt, G.C. (Eds.) (1969) Readings in the Concept \& Measurement of Income, pp.132-138, University Press, Cambridge.

Hicks, J.R. (1946) Value and Capital, 2nd ed., Clarendon Press, Oxford.

Ijiri, Y. (1967) The Foundations of Accounting Measurement, Prentice-Hall, New Jersey.

Ijiri, Y. (1975) Theory of Accounting Measurement, SAR No. 10, AAA, Florida.

Ijiri, Y. and Kaplan, R.S. (1969) 'Probabilistic depreciation and its implications for group depreciation', The Accounting Review, Vol. 44, No. 3, pp.743-756.

Institute of Chartered Accountants in England and Wales (ICAEW, N15) (1952) Rising Price levels in relation to Accounts, Recommendation N15, London.

International Accounting Standards Board (IASB) (2008) Preliminary Views on Revenue Recognition in Contracts with Customers, Discussion paper, Joint Project of IASB and FASB.

International Accounting Standards Board (IASB) (2010) Exposure Draft Revenue from Contracts with Customers, Joint ED of IASB and FASB.

Jensen, M.C. and Meckling, W.H. (1976) 'Theory of the firm: managerial behavior, agency costs and ownership structure’, Journal of Financial Economics, 3, pp.305-360. 
Johnston, T.R. (1949) 'The nature and purpose of accounting', The Accountants' Journal (N.Z.), Vol. 28, No. 3, pp.58-68.

Johnston, T.R. (1951) 'The double entry technique', The Accountants' Journal (N.Z.), Vol. 30, No. 2, p.53.

Johnston, T.R., Jager, M. and Taylor, R. (1983) The Law and Practice of Company Accounting in Australia, 5th ed., Butterworths, Sydney.

Kaldor, N. (1955) 'The concept of income in economic theory', An Expenditure Tax, Allen and Unwin, London, reprinted in Parker, R.H. and Harcourt, G.C. (Eds.) (1969) Readings in the Concept \& Measurement of Income, pp.127-131, University Press, Cambridge.

Kaplan, A. (1964) The Conduct of Enquiry, Chandler, San Francisco.

Kennedy, C. (1986) 'Inflation accounting: retrospect and prospect', in Parker, R.H., Harcourt, G.C. and Whittington, G. (Eds.): Readings in the Concept and Measurement of Income, 2nd ed., pp.179-199, Philip Allan, Oxford.

Keynes, J.M. (1930) A Treatise on Money Volume I, Macmillan, London.

Knight, F. (1921) Risk, Uncertainty and Profit, Harper and Row, New York.

Kothari, S.P. and Lester, R. (2012) 'The role of accounting in the financial crisis: lessons for the future', Accounting Horizons, Vol. 26, No. 2, pp.335-351.

Krantz, D.H., Luce, R.D., Suppes, P. and Tversky, A. (1971) Foundations of Measurement V.1, Academic Press, New York.

Kuhn, T. (1970) The Structure of Scientific Revolutions, 2nd enlarged ed., The University of Chicago Press, Chicago.

La Porta, R., Lopez-de-Silanes, F. and Shleifer, A. (LLS) (2008) 'The economic consequences of legal origins', Journal of Economic Literature, Vol. 46, No. 2, pp.285-332.

La Porta, R., Lopez-de-Silanes, F., Shleifer, A. and Vishny, R.W. (LLSV) (1997) 'Legal determinants of external finance', The Journal of Finance, Vol. L11, No. 3, pp.1131-1150.

La Porta, R., Lopez-de-Silanes, F., Shleifer, A. and Vishny, R.W. (LLSV) (1998) 'Law of finance’, Journal of Political Economy, Vol. 106, No. 6, pp.1113-1155.

Lane, J. and Willett, R. (1997) 'Depreciation need not be arbitrary', Accounting and Business Research, Vol. 27, No. 3, pp.179-194.

Larson, K.D. (1969) 'Implications of measurement theory on accounting concept formulation', The Accounting Review, Vol. 44, No. 1, pp.38-47.

Lennard, A. (2007) 'Stewardship and the objectives of financial statements: a comment on the IASB's preliminary views on an improved conceptual framework for financial reporting: the objective of financial reporting and qualitative characteristics of decision-useful financial reporting information', Accounting in Europe, Vol. 4, Nos. 1-2, pp.51-66.

Littleton, A.C. (1933) Accounting Evolution to 1900, Russell and Russell, New York.

Luce, R.D. and Krumhansl, C.L. (1988) 'Measurement, scaling and psychophysics', in Atkinson, R.C., Herrnstein, R.J., Lindzey, G. and Luce, R.D. (Eds.): Stevens Handbook of Experimental Psychology, 2nd ed., John Wiley and Sons, New York.

MacNeal, K. (1939) Truth in Accounting, reprinted 1970, Scholars Book Co., Kansas.

Mattessich, R. (1957) 'Towards a general and axiomatic foundation of accountancy - with an introduction to the matrix formulation of accounting systems', Accounting Research, October, Vol. 8, pp.328-355, reprinted in Zeff, S.A. (1982) The Accounting Postulates and Principles Controversy of the 1960s, Garland, New York.

Mattessich, R. (1964a) Accounting and Analytical Methods, Irwin, New York.

Mattessich, R. (1964b) Accounting and Analytical Methods, reprinted in 1977 with additional preface to the reprint edition, Scholars Book Co., Kansas.

Mattessich, R. (1972) 'Methodological preconditions and problems of a general theory of accounting', The Accounting Review, Vol. 47, No. 3, pp.469-470. 
Mattessich, R. (1984) Modern Accounting Research: History, Survey and Guide, Research Monograph No. 7, 2nd printing 1989, The Canadian Certified General Accountants' Research Foundation, Vancouver.

Mattessich, R. (1995) Critique of Accounting Examination of the Foundations and Normative Structure of an Applied Discipline, Quorum Books, Westport, Connecticut.

May, G.O. (1943a) Financial Accounting: A Distillation of Experience, The Macmillan Co., New York.

May, G.O. (1943b) 'Improvements in financial accounts', Dickinson Lectures in Accounting, Harvard University Press, reprinted in Zeff, S. (Ed.) (1978) Selected Dickinson Lectures in Accounting 1936-1952, pp.3-48, Arno Press, New York.

May, G.O. (1950) 'The case against change in the present methods of accounting for exhauston of business property', paper in Alexander, S.S., Bronfenbrenner, M., Fabricant, S. and Warburton, C. (1973) Five Monographs on Business Income, pp.261-271, Scholars Book Co., Kansas.

McLean, B. and Elkind, P. (2003) The Smartest Guys in the Room the Amazing Rise and the Scandalous Fall of Enron, Portfolio, New York.

McWalters, C.S. (1998) 'Accounting thought, practice and legislation: early Canadian evidence', Accounting History NS, Vol. 3, No. 2, pp.103-142.

Menard, C. and Shirley, M.M. (2011) 'The contribution of Douglas North to new institutional economics', forthcoming in Economic Institutions, Rights, Growth, and Sustainability, Cambridge University Press, Cambridge (NEP; halshs-00624297, Version $1-22$ September 2011).

Mill, J.S. (1891) Principles of Political Economy, George Routledge and Sons, Ltd., London.

Montier, J. (2002) Behavioural Finance: Insights into Irrational Minds and Markets, John Wiley and Sons Ltd, New York.

Moonitz, M. (1961) The Basic Postulates of Accounting, ARS No. 1, AICPA, New York.

Mouck, T. (1989) 'The irony of 'the golden age' of accounting methodology', The Accounting Historians Journal, Vol. 16, No. 2, pp.85-106.

Mouck, T. (1993) 'The revolution in financial reporting theory: a Kuhnian interpretation', The Accounting Historians Journal, Vol. 20, No. 1, pp.33-57.

Nagel, E. and Newman, J.R. (1959) Godel's Proof, Routledge \& Kegan Paul Ltd, London.

Nelson, E.G. (1942) 'The relation between the balance sheet and the profit and loss statement', The Accounting Review, Vol. 17, No. 2, pp.132-141.

North, D.C. (1994) 'Economic performance through time', American Economic Review, Vol. 84, No. 3, pp.359-368.

North, D.C. (2005) Understanding the Process of Economic Change, Princeton University Press, USA.

OCED (2003) Oxford Compact English Dictionary, revised 3rd ed., C. Soanes (Ed.), University Press, Oxford.

Parker, R.H. (1965) 'Lower of cost and market in Britain and the United States: an historical survey’, Abacus, Vol. 1, No. 2, pp.156-172.

Parker, R.H. and Harcourt, G.C. (Eds.) (1969) Readings in the Concept \& Measurement of Income, University Press, Cambridge.

Parker, R.H., Harcourt, G.C. and Whittington, G. (Eds.) (1986) Readings in the Concept and Measurement of Income, 2nd ed., Philip Allan, Oxford.

Paton, W.A. (1922) Accounting Theory, reprinted 1973, Scholars Book Co., Kansas.

Paton, W.A. and Littleton, A.C. (1940) An Introduction to Corporate Accounting Standards, Monograph No. 3, American Accounting Association, Evanston, Illinois.

Popper, K.R. (1959) The Logic of Scientific Discovery, Hutchinson \& Co. Ltd., London. 
Previts, G.J. and Merino, B.D. (1998) A History of Accountancy in the United States, Ohio State University Press, Columbus.

Rayman, R.A. (2006) Accounting Standards: True or False?, Routledge Taylor \& Francis Group, London and New York.

Reiter Jr., P. (1926) Profits, Dividends and the Law, Ronald Press Co., New York, reprinted 1976, Arno Press, New York.

Robbins, L.C. (1937) The Nature and Significance of Economic Science, Macmillan and Co. Ltd, London.

Rorem, C.R. (1937) 'Accounting theory: a critique of the tentative statement of accounting principles', The Accounting Review, Vol. 12, No. 2, pp.133-138.

Rudner, R.S. (1966) Philosophy of Social Science, Prentice Hall, New Jersey.

Ryan, J.B. (1970) 'Towards truth in accounting', Paper presented at the Annual Conference of the Australasian Association of University Teachers of Accounting (later renamed the Accounting Association of Australia and New Zealand), August 1970, Adelaide, Australia, pp.D1-19.

Ryan, J.B. (2007) 'The relationship between accounting profit and economic income', Australian Accounting Review, Vol. 17, No. 43, pp.33-46.

Ryan, J.B., Heazlewood, C.T. and Andrew, B.H. (1977) Australian Company Financial Reporting: 1975 Accounting Research Study No. 7, Australian Accounting Research Foundation, Melbourne.

Salvary, S.C. (1985) Accounting: A Library of Quantifications, McQueen Accounting Monograph Series Vol. 1, University of Arkansas, Fayetteville.

Salvary, S.C. (1989) An Analytical Framework For Accounting Theory, McQueen Accounting Monograph Series Vol. 5, University of Arkansas, Fayetteville.

Salvary, S.C. (1992) 'Recoverable cost: the basis of a general theory of financial accounting measurement', Accounting Enquiries, Vol. 1, No. 2, pp.233-273.

Samuelson, R.A. (1996) 'The concept of assets in accounting theory', Accounting Horizons, Vol. 10, No. 3, pp.147-157.

Schipper, K. and Vincent, L. (2003) 'Earnings quality’, Accounting Horizons, Vol. 17, Supplement, pp.97-110.

Shiller, R.J. (2005) Irrational Exuberance, 2nd ed., Princeton University Press, Princeton.

Shleifer, A. (2000) Inefficient Markets: An Introduction to Behavioral Finance, [electronic resource] Oxford University Press, New York.

Shwayder, K. (1967) 'A critique of economic income as an accounting concept', Abacus, Vol. 3, No. 1, pp.23-26.

Simons, H.C. (1938) 'The definition of income', Personal Income Taxation, University of Chicago Press, reprinted in Parker, R.H. and Harcourt, G.C. (Eds.) (1969) Readings in the Concept and Measurement of Income, University Press, Cambridge.

Sprague, C.E. (1880) 'The algebra of accounts', Series of articles in The Book-keeper, July and August, New York, Office of Publications, 76 Chalmers St., reprinted in Vol. 1, The Bookkeeper and American Counting-Room, 1989, Garland Publishing Inc., New York and London.

Sprague, C.E. (1901) The General Principles of the Science of Accounts, reprinted 1984, Garland, New York.

Sprouse, R.T. (1966) ‘Accounting for what-you-may-call-its’, Journal of Accountancy, Vol. 122, No. 4, pp.45-53.

Stamp, E. (1983) 'Does the chamber' evidence support the CoCoA system?', Accounting and Business Research, Vol. 13, No. 50, pp.119-127.

Sterling, R.R. (1967) 'Conservatism: the fundamental principle of valuation in traditional accounting', Abacus, Vol. 3, No. 2, pp.109-132.

Sterling, R.R. (1970) Theory of the Measurement of Enterprise Income, The University Press of Kansas, Kansas. 
Stevens, S.S. (1946) 'On the theory of scales of measurement', Science, Vol. 103, No. 2684, pp.677-680.

Stiglitz, J.E. (1993) Economics, WW Norton and Company, USA.

Storey, R.K. and Storey, S. (1998) Special Report The Framework of Financial Accounting Concepts and Standards, Financial Accounting Series No. 181-C, FASB, Norwalk.

Suppe, F. (1977) The Structure of Scientific Theories, University of Illinois Press, Illinois.

Suppes, P. and Zinnes, J.L. (1965) 'Basic measurement theory', Chap. 1, Vol. 1 in Luce, R.D., Bush, R.R. and Galanter, E. (Eds.): Handbook of Modern Psychology, John Wiley and Sons, New York.

Thomas, A.L. (1974) The Allocation Problem: Part Two, SAR No. 9, AAA, Florida.

United States Securities and Exchange Commission (2008) Report and Recommendations Pursuant to Section 133 of the Emergency Economic Stabilization Act of 2008: Study on Mark-To-MarketAccounting, USA.

Vatter, W.J. (1966) 'Obstacles to the specification of accounting principles', Chapter 5 in Jaedieke, K.K., Ijiri, Y. and Nelson, O. (Eds.): Research in Accounting Measurement, AAA, Evanston, Illinois.

Vickrey, D.W. (1970) 'Is accounting a measurement discipline?', The Accounting Review, Vol. 53, No. 3, pp.731-742.

Vickrey, D.W. (1975) An analysis of the Major Numerical Assignments of Three Frequently Advocated Accounting Systems from the Perspective of the Theory of Fundamental Measurement, PhD dissertation, University of Texas at Austin (from an authorised copy, London University Microfilms International, 1996).

Vickrey, D.W. (1976) 'General-price-level-adjusted historical cost statements and the ratio-scale view', The Accounting Review, Vol. 51, No. 1, pp.31-40.

Walker, D.M. (1980) The Oxford Companion to Law, Clarendon Press, Oxford.

Warrell, C.J. (1989) 'The concept and measurement of depreciation', Chapter 8 in Kerr, J.St.G. and Clift, R.C. (Eds.)” Essays in Honour of Louis Goldberg, pp.173-191, Department of Business Law and Accounting, The University of Melbourne.

Watts, R.L. and Zimmerman, J.L. (1979) 'The demand for and supply of accounting theories: the market for excuses', The Accounting Review, Vol. 54, No. 2, pp.273-305.

Wells, M.C. (1976) 'A revolution in accounting thought?', The Accounting Review, Vol. 51, No. 3, pp.471-482.

Whittington, G. (1985) 'Financial accounting theory: an overview', The British Accounting Review, Vol. 16, No. 1, pp.4-41.

Willett, R. (1987) 'An axiomatic theory of accounting measurement', Accounting and Business Research, Vol. 17, No. 66, pp.155-171.

Willett, R. (1988) 'An axiomatic theory of accounting measurement - Part II', Accounting and Business Research, Vol. 19, No. 73, pp.79-91.

Williams, S.J. (2003) 'Assets in accounting: reality lost', Accounting Historians Journal, Vol. 30, No. 2, pp.133-174.

Williamson, O.E. (1985) The Economic Institutions of Capitalism, Free Press, New York.

Williamson, O.E. (2000) 'The new institutional economics: taking stock, looking ahead', Journal of Economic Literature, Vol. 38, No. 3, pp.595-613.

Yamey, B.S. (1962a) 'Some topics in the history of financial accounting in England 1500-1900', in Baxter, W.T. and Davidson, S. (Eds.): Studies in Accounting Theory, pp.14-43, Sweet and Maxwell Ltd, London.

Yamey, B.S. (1962b) 'The case law relating to company dividends', in Baxter, W.T. and Davidson, S. (Eds.): Studies in Accounting Theory, pp.428-442, Sweet and Maxwell Ltd., London. 
Young, J.J. (1995) 'Getting the accounting 'right': accounting and the savings and loan crisis', Accounting, Organizations and Society, Vol. 20, No. 1, pp.55-80.

Zeff, S.A. (1966) The American Accounting Association Its First 50 Years, AAA, Florida.

Zeff, S.A. (1974) 'F.R.M. de PAULA', The Accounting Historians Journal, Vol. 1, No. 4, pp.3134 (also sourced as The Accounting Historian October, p.6).

Zeff, S.A. (1999) 'The evolution of the conceptual framework of business enterprises in the United States', Accounting Historians Journal, Vol. 26, No. 2, pp.89-131.

\section{Appendix A}

\section{The DEC and the general postulates of financial accounting}

\section{Introduction to the DEC}

The DEC is the term used to describe the set of basic elements, equations and relationships underlying double entry accounting together with the assumptions, general concepts and logic justifying those equations. As a general system, double entry accounting can form the basis of a number of individual systems, or interpretations. These may include, for example, historical cost accounting (HCA), constant purchasing power accounting (CPP), current cost accounting (CCA), or continuously contemporary accounting (CoCoA). Thus, the DEC provides a common structure which can be used to evaluate the internal consistency of systems for the measurement of profit and capital. However, for the calculus to be accepted as a theory, at least one interpretation must be accepted as empirically valid.

The calculus includes five point-of-time elements, including owners' equity and its components, capital and retained profits. Thus owners' equity, while redundant, is retained as it simplifies the analysis. Changes in assets and liabilities are the primitive or undefined terms, and they are further subdivided so that the changes for a period can be aggregated by the relevant source. Altogether there are 23 elements. With 15 being defined within the calculus, eight are primitive terms. These primitive elements take their meaning from outside the calculus, and, in order to constitute a valid theory, they should be empirically testable. Changes in assets and liabilities are selected as the primitives since in most cases they can be tested directly. These changes are based on executed contracts with the resulting transactions providing the fundamental measurements.

The formal calculus is underpinned by one main axiom (1) stating the fundamental equality in terms of changes in the elements of the double entry equation. The profit theorem (3) derived from this axiom, demonstrates the well known result that, abstracting from the changes in net assets caused by the introduction or withdrawal of capital or dividends, profit is represented by an increase in net assets. Many writers (for example, Folsom, 1873; Sprague, 1880, 1901; Johnston, 1951) have demonstrated why the equality is maintained over the several kinds of transactions. 


\section{Exhibit 1 - the DEC}

\section{Elements of the system and symbols representing them}

Point-of-time elements:

- $\quad \mathrm{A}_{\mathrm{t}}=$ quantity of assets at time $\mathrm{t}$

- $\mathrm{L}_{\mathrm{t}}=$ quantity of liabilities at time $\mathrm{t}$

- $\mathrm{OE}_{\mathrm{t}}=$ quantity of owners' equity at time $\mathrm{t}$

- $\mathrm{C}_{\mathrm{t}}=$ quantity of capital at time $\mathrm{t}$

- $\mathrm{RP}_{\mathrm{t}}=$ quantity of retained profits at time $\mathrm{t}$.

Change in the point-of-time elements:

- $\mathrm{A}_{(\mathrm{t})}=$ change in the quantity of assets for period ended at time $\mathrm{t}$

- $\mathrm{L}_{(\mathrm{t})}=$ change in the quantity of liabilities for period ended at time $\mathrm{t}$

- $\mathrm{OE}_{(\mathrm{t})}=$ change in the quantity of owners' equity for period ended at time $\mathrm{t}$

- $\mathrm{C}_{(\mathrm{t})}=$ change in the quantity of capital for period ended at time $\mathrm{t}$

- $\quad \mathrm{RP}_{(\mathrm{t})}=$ change in the quantity of retained profits for period ended at time $\mathrm{t}$.

Change in assets and liabilities identified by the source or application:

- $\quad \mathrm{A}_{(\mathrm{t}) \mathrm{l}}=$ change in the quantity of assets for period ended at time t for which the source was liabilities

- $\quad \mathrm{A}_{(\mathrm{t}) \mathrm{c}}=$ change in the quantity of assets for period ended at time $\mathrm{t}$ for which the source was capital

- $\quad \mathrm{A}_{(\mathrm{t}) \mathrm{r}}=$ change in the quantity of assets for period ended at time $\mathrm{t}$ for which the source was revenue

- $\quad \mathrm{A}_{(\mathrm{t}) \mathrm{e}}=$ change in the quantity of assets for period ended at time $\mathrm{t}$ brought about by expenses

- $\quad \mathrm{A}_{(\mathrm{t}) \mathrm{d}}=$ change in the quantity of assets for period ended at time $\mathrm{t}$ brought about by drawings or dividends

- $\mathrm{L}_{(\mathrm{t}) \mathrm{a}}=$ change in the quantity of liabilities for period ended at time $\mathrm{t}$ applied to assets

- $\quad \mathrm{L}_{(\mathrm{t}) \mathrm{e}}=$ change in the quantity of liabilities for period ended at time $\mathrm{t}$ applied to expenses

- $\mathrm{L}_{(\mathrm{t}) \mathrm{r}}=$ change in the quantity of liabilities for period ended at time $\mathrm{t}$ for which the source was revenue

- $\mathrm{L}_{(\mathrm{t}) \mathrm{c}}=$ change in the quantity of liabilities for period ended at time $\mathrm{t}$ for which the source was capital. 
Periodic elements, showing changes in RP:

- $\quad \mathrm{P}_{[\mathrm{t}]}=$ quantity of profit for period ended at time $\mathrm{t}$

- $\mathrm{R}_{[\mathrm{t}]}=$ quantity of revenue for period ended at time $\mathrm{t}$

- $\mathrm{E}_{[\mathrm{t}]}=$ quantity of expenses for period ended at time $\mathrm{t}$

- $\mathrm{D}_{[\mathrm{t}]}=$ quantity of drawings or dividends for period ended at time $\mathrm{t}$.

Many of these elements can be expressed as combinations of the others. The minimum number in terms of which all others can be defined is eight. These eight have been chosen as primitive elements because they summarise changes in assets and liabilities by their source.

\section{Primitive elements}

$$
\begin{array}{lllll}
\mathrm{A}_{(t) c} & \mathrm{~A}_{(\mathrm{t}) \mathrm{r}} & \mathrm{A}_{(\mathrm{t}) \mathrm{e}} & \mathrm{A}_{(\mathrm{t}) \mathrm{d}} & \mathrm{A}_{(\mathrm{t}) 1} \\
\mathrm{~L}_{(\mathrm{t}) \mathrm{c}} & \mathrm{L}_{(\mathrm{t}) \mathrm{r}} & \mathrm{L}_{(\mathrm{t}) \mathrm{e}} & &
\end{array}
$$

Of the remaining elements, given a quantity at time zero (i.e., an initial dated circumstance) the point-of-time elements can be defined either by defining the change in them in terms of the point of time elements by

$$
X_{(t)}=X_{t}-X_{t-1}
$$

(This gives a general definition, where $\mathrm{X}$ can be any of $\mathrm{A}, \mathrm{L}, \mathrm{OE}, \mathrm{C}$, or RP) or by defining the point-of-time elements in terms of the change of the point-of-time elements. The latter definition, shown as the first of the definitions, is used because it facilitates identification of the selected primitives.

\section{Definitions}

$$
\begin{aligned}
& \text { D1 } \mathrm{X}_{\mathrm{t}}=\mathrm{X}_{(\mathrm{t})}+\mathrm{X}_{\mathrm{t}-1} \\
& =\sum_{\mathrm{n}=1}^{\mathrm{t}} \mathrm{X}_{(\mathrm{n})}+\mathrm{X}_{0} \\
& \text { D2 } A_{(t)}=A_{(t) l}+A_{(t) c}+A_{(t) r}-A_{(t) e}-A_{(t) d} \\
& \text { D3 } \mathrm{L}_{(\mathrm{t})}=\mathrm{L}_{(\mathrm{t}) \mathrm{a}}+\mathrm{L}_{(\mathrm{t}) \mathrm{e}}-\mathrm{L}_{(\mathrm{t}) \mathrm{r}}-\mathrm{L}_{(\mathrm{t}) \mathrm{c}} \\
& \text { D4 } \mathrm{L}_{(\mathrm{t}) \mathrm{a}}=\mathrm{A}_{(\mathrm{t}) 1} \\
& \text { D5 } \mathrm{C}_{(\mathrm{t})}=\mathrm{A}_{(\mathrm{t}) \mathrm{c}}+\mathrm{L}_{(\mathrm{t}) \mathrm{c}} \\
& \text { D6 } \mathrm{R}_{[\mathrm{t}]}=\mathrm{A}_{(\mathrm{t}) \mathrm{r}}+\mathrm{L}_{(\mathrm{t}) \mathrm{r}} \\
& \text { D7 } \mathrm{E}_{[\mathrm{t}]}=\mathrm{A}_{(\mathrm{t}) \mathrm{e}}+\mathrm{L}_{(\mathrm{t}) \mathrm{e}} \\
& \text { D8 } \quad \mathrm{D}_{[\mathrm{t}]}=\mathrm{A}_{(\mathrm{t}) \mathrm{d}} \\
& \text { D9 } \mathrm{RP}_{(\mathrm{t})}=\mathrm{A}_{(\mathrm{t})}-\mathrm{L}_{(\mathrm{t})}-\mathrm{C}_{(\mathrm{t})}
\end{aligned}
$$




$$
\begin{aligned}
& \text { D10 } \mathrm{P}_{[\mathrm{t}]}=\mathrm{RP}_{(\mathrm{t})}+\mathrm{D}_{[\mathrm{t}]} \\
& \text { D11 } \mathrm{OE}_{(\mathrm{t})}=\mathrm{C}_{(\mathrm{t})}+\mathrm{RP}_{(\mathrm{t})} \text {. }
\end{aligned}
$$

\section{Axioms}

- Basic equality

$$
\mathrm{OE}_{(\mathrm{t})}=\mathrm{A}_{(\mathrm{t})}-\mathrm{L}_{(\mathrm{t})} \text {. }
$$

- Conditional capital maintenance distribution axiom

$$
\mathrm{RP}_{\mathrm{t}} \geq 0 \text {. }
$$

\section{Theorems}

\section{The profit theorem}

$$
P_{[t]}=R_{[t]}-E_{[t]}
$$

(3) was obtained from (4) by substituting from D6 and D7 for the expressions on the rhs.

$$
\mathrm{P}_{[\mathrm{t}]}=\left(\mathrm{A}_{(\mathrm{t})}+\mathrm{L}_{(\mathrm{t}) \mathrm{r}}\right)-\left(\mathrm{A}_{(\mathrm{t}) \mathrm{e}}+\mathrm{L}_{(\mathrm{t}) \mathrm{e}}\right)
$$

(4) was derived by first substituting into (1) for $\mathrm{OE}_{(\mathrm{t})}$ from $\mathrm{D} 11$; and then for $\mathrm{RP}_{(\mathrm{t})}$ from D10 to give on re-arranging:

$$
\mathrm{P}_{[\mathrm{t}]}=\mathrm{A}_{(\mathrm{t})}-\mathrm{L}_{(\mathrm{t})}-\left(\mathrm{C}_{(\mathrm{t})}-\mathrm{D}_{[\mathrm{t}]}\right)
$$

Then substituting for all the elements on the right hand side from D2, D3, D5 and D8 gives:

$$
\begin{aligned}
P_{[t]}= & A_{(t) l}+A_{(t) c}+A_{(t) r}-A_{(t) e}-A_{(t) d}-L_{(t) a} \\
& -L_{(t) e}+L_{(t) r}+L_{(t) c}-A_{(t) c}-L_{(t) c}+A_{(t) d}
\end{aligned}
$$

Utilising D4 and simplifying gives (4) above.

Capital maintenance distribution theorem

$$
\mathrm{D}_{[\mathrm{t}]} \leq \mathrm{RP}_{\mathrm{t}-1}+\mathrm{P}_{[\mathrm{t}]}
$$

This is derived from Axiom (2), and D10 after first using D1 to substitute into D10 for $\mathrm{RP}_{(\mathrm{t})}$ to give:

$$
R P_{t}=R P_{t-1}+P_{t t]}-D_{[t]} \geq 0
$$

This is then re-arranged to give Theorem (5).

The relationship of this theorem to capital may be shown. Applying D1 to the elements of D9 enables them to be written as point-of-time elements, and then substituting from the above for $\mathrm{RP}_{\mathrm{t}}$ gives: 


$$
\mathrm{RP}_{\mathrm{t}-1}+\mathrm{P}_{\mathrm{t}]}-\mathrm{D}_{[\mathrm{t}]}=\mathrm{A}_{\mathrm{t}}-\mathrm{L}_{\mathrm{t}}-\mathrm{C}_{\mathrm{t}}
$$

Therefore, from the last two equations we can write:

$$
\mathrm{A}_{\mathrm{t}}-\mathrm{L}_{\mathrm{t}} \geq \mathrm{C}_{\mathrm{t}}
$$

This demonstrates that, applying Axiom (2), capital will not be distributed.

\section{Balance sheet theorem}

A symbolic representation of the balance sheet can be obtained from D1 and (1)

$$
\mathrm{OE}_{\mathrm{t}}=\mathrm{A}_{\mathrm{t}}-\mathrm{L}_{\mathrm{t}}
$$

\section{Introduction to the general postulates}

The additional definitions and postulates for relating the DEC to the environment are now introduced. They comprise ten definitions and seven postulates. The term 'postulates' is used rather than axioms as the statements comprising the system of postulates have not been developed as fully as the axioms of the DEC. It needs to be appreciated that no matter what level at which a theory is considered, there will always be propositions lying outside the particular theory of reference which are needed for its application and full understanding $^{26}$. Neither the DEC nor the statement of general postulates are exceptions to this rule.

Nevertheless, the statement of postulates serves the useful purpose of prescribing the requirements and assumptions for an explanation of external financial reporting of performance and financial position. It should also be noted that knowledge is "systematically presupposed" [Rudner, (1966), p.48] whenever relevant. In the DEC, for example, simple rules of algebra and arithmetic have been assumed. In the postulates statement, English grammar and the meaning of many simple words has been presupposed. Of course, the meaning of terms or procedures presupposed is always open to challenge. In defining the general definitions an attempt has been made to use simple and clear terms.

Postulate 1 states the objectives of financial accounting, and Postulates 2, 3 and 4 provide the means for the application of the general accounting system, the DEC. Of these, Postulate 4 states the steps to be applied for conferring specific meaning on the accounting elements [rules of interpretation, or auxiliary hypotheses (Mattessich, 1972)] from the recognised information needs. Postulates 5 and 6 assume that the required information including a unit of account is available, and Postulate 7 asserts that the resulting accounting information will provide a true and fair view for the information needs recognised. 


\section{Exhibit 2}

General postulates of financial accounting

\section{Definitions}

1 Assets are economic resources owned by an entity through the holding of relevant property rights.

2 Liabilities are obligations for future payments by an entity for economic value received.

3 Owners' equity is the ownership interest in assets less liabilities of an accounting entity.

4 Transactions are changes in the amount or form of assets, liabilities or owners' equity, of an accounting entity.

5 Accounting entity is the set of assets and liabilities identified by common ownership and economic interest.

6 Users are persons with an economic interest in an accounting entity who require accounting information to satisfy their financial information needs.

7 Relevant information is information for satisfaction of a financial information need, or for the taking of a decision, or necessary to discharge a financial reporting responsibility.

8 Reliable information is information which faithfully measures the quantity which it purports to measure, and which is verifiable.

9 The $D E C$ is the general, axiomatic system describing the relationships between the assets, liabilities, owners' equity (referred to generally as the accounting elements) and transactions of an accounting entity for the purpose of measuring results over a period of time, and the amount and form of the assets, liabilities and owners' equity at a point of time.

10 Financial statements are the means used for measuring and communicating -

a the results from using the assets and liabilities over a period of time of an accounting entity

b the amount and present form of the assets and liabilities and owners' equity at a point of time for that accounting entity.

\section{Postulates}

1 The objective of financial accounting is to provide users with relevant and reliable accounting information for their recognised, financial information needs in respect of an accounting entity.

2 The objective is achieved by identifying, recording and measuring the assets, liabilities, owners' equity and transactions of an accounting entity; and by communicating relevant and reliable information in respect of that accounting entity in financial statements to users. 
3 Measurement of assets, liabilities, owners' equity and transactions of an accounting entity requires the identification and selection of a qualitative, empirical property able to bring all the elements into a common relationship.

4 The application of the DEC to a particular accounting entity for the measurement of operating results and the amount and form of assets, liabilities and owners' equity requires -

a selection from the common financial information needs of users of information needs that can be recognised in a specific interpretation of the DEC

b selection from those common financial information needs recognised in a of the qualitative, empirical property

c deduction from the qualitative empirical property selected in b of the relevant quantity of the changes in A and L identified as the primitive terms of the DEC, interpretation of the other accounting elements, and selection of the standard unit of account

d derivation from the foregoing of relevant accounting policies for measurement of the derived quantities of the assets, liabilities and owners' equity and transactions

e a statement of the relevant circumstances (the opening dated position, accounting policies, continuity concept - if justified - and transactions of the period).

5 A standard unit of account is available for measuring the relevant quantity of assets, liabilities, owners' equity and transactions.

6 The accounting entity, users, their recognised, common, financial information needs, and relevant circumstances can all be identified.

7 Financial statements prepared in accordance with these postulates will provide a true and fair view of the information disclosed for the information needs recognised.

\section{Appendix B}

\section{Examples of financial statements}

\section{Part 1: monetary profit measurement}

\section{Part 2: wealth measurement}

The statements which follow have been prepared from information disclosed in the Comprehensive Business Reporting Model, Financial Reporting for Investors July 2007, of the Centre for Financial Market Integrity of the CFA Institute. Wherever their assumptions or amounts have been varied, the reason is disclosed. 
Part 1: statements demonstrating monetary profit measurement, and related statements including retained profits, cash flow, balance sheet and commitments

Information needs of shareholders recognised or assumed: These financial statements disclose monetary profit for 20x4, and retained profits as at 31 December 20x4, available for dividend payments after maintaining the paid in money capital. Together with the articulated balance sheet, cash flow statement and statement of commitments, the statements also represent the directors' report to shareholders on their stewardship of the money capital and retained profits, and the amount and form of the funds committed to the business, i.e., assets less liabilities.

Table 1 Monetary profit statement for year ended 31 December 20x4

\begin{tabular}{|c|c|c|}
\hline $\begin{array}{l}\text { Sales revenue } \\
\text { Less cost of sales expense }\end{array}$ & & $\begin{array}{c}€ 2,775,000 \\
1,505,306 \\
\end{array}$ \\
\hline Gross margin & & $1,269,694$ \\
\hline \multicolumn{3}{|l|}{ Less other expenses } \\
\hline \multicolumn{3}{|l|}{ Production } \\
\hline Direct labour & 110,000 & \\
\hline Operating & 150,000 & \\
\hline Rent - leased factory & 7,500 & \\
\hline \multicolumn{3}{|l|}{ Selling and administration } \\
\hline Bad debts & 50,500 & \\
\hline Compensation & 107,500 & \\
\hline Pension & 3,600 & \\
\hline Rent & 120,000 & \\
\hline Depreciation - main building & 175,000 & \\
\hline \multicolumn{3}{|l|}{ Financial } \\
\hline Interest & $\underline{250,000}$ & $\underline{974,100}$ \\
\hline Operating profit & & 295,594 \\
\hline \multicolumn{3}{|l|}{ Add other revenue } \\
\hline Dividends from investments & & $\underline{9,250}$ \\
\hline Monetary profit before income tax expense & & 304,844 \\
\hline Less income tax expense & & $\underline{75,451}$ \\
\hline Monetary profit for $20 \mathrm{x} 4$ & & $€ 229,393$ \\
\hline Table 2 Balance sheet as at 31 Decembe & & \\
\hline \multicolumn{3}{|l|}{ Current assets } \\
\hline Bank & & $€ 5,918,411$ \\
\hline Accounts receivable & 845,000 & \\
\hline Less allowance for doubtful accounts & $\underline{70,500}$ & 774,500 \\
\hline Inventories - at cost & & $\underline{619,694}$ \\
\hline Total current assets & & $\underline{7,312,605}$ \\
\hline
\end{tabular}


Financial accounting reform

Table 2 Balance sheet as at 31 December 20x4 (continued)

\begin{tabular}{|c|c|c|}
\hline Non-current assets & & \\
\hline $\begin{array}{r}\text { Marketable securities (at cost) } \\
\text { (Market value: } \$ 196,100 \text { ) }\end{array}$ & & 185,000 \\
\hline Investment in affiliate (at cost) & & 710,000 \\
\hline Building - at cost & $4,100,000$ & \\
\hline less accumulated depreciation & $\underline{275,000}$ & \\
\hline Net building & & $\underline{3,825,000}$ \\
\hline Total non-current assets & & $\underline{4,720,000}$ \\
\hline Total assets & & $€ 12,032,605$ \\
\hline \multicolumn{3}{|l|}{ Share capital and reserves } \\
\hline Common stock (less 100,000 repurchased) & & $€ 4,500,000$ \\
\hline Retained profits & & $\underline{3,228,354}$ \\
\hline Total funds of common stockholders' & & $7,728,354$ \\
\hline Perpetual preferred stock (return of capital preferred) ${ }^{(1)}$ & & $\underline{400,000}$ \\
\hline Total share capital and reserves & & $\underline{8,128,354}$ \\
\hline \multicolumn{3}{|l|}{ Non-current liabilities } \\
\hline Bonds due ...@...\% & & $2,500,000$ \\
\hline Accrued pension liability & & $\underline{4,800}$ \\
\hline Total term funds & & $\underline{2,504,800}$ \\
\hline \multicolumn{3}{|l|}{ Currentliabilities } \\
\hline Accounts payable & & 375,000 \\
\hline Accrued liabilities & & 78,000 \\
\hline Advances from customers & & 190,000 \\
\hline Lease expense (land and building) & & 7,500 \\
\hline Accrued stock compensation & & 13,500 \\
\hline Short-term debt & & 500,000 \\
\hline Interest payable & & 125,000 \\
\hline Income tax payable & & 75,451 \\
\hline Dividend payable & & $\underline{35,000}$ \\
\hline Total current liabilities & & $\underline{1,399,451}$ \\
\hline Total shareholders' funds and liabilities & & $€ 12,032,605$ \\
\hline
\end{tabular}

Note: ${ }^{(1)}$ As information is not available for preparation of consolidated accounts, the minority interest has been disposed of by adding to the preferred stock. 
Table 3 Retained profits statement for year ended 31 December 20x4

\begin{tabular}{|c|c|c|c|}
\hline \multicolumn{3}{|c|}{ Balance brought forward 1.1.20x4 } & $€ 3,045,262$ \\
\hline \multicolumn{3}{|c|}{ Add adjustment - deferred income tax reversed } & $\underline{23,699}$ \\
\hline \multicolumn{3}{|c|}{ Adjusted profits brought forward } & $3,068,961$ \\
\hline \multicolumn{3}{|c|}{ Add Profit for $20 \mathrm{x} 4$} & $\underline{229,393}$ \\
\hline \multicolumn{3}{|c|}{ Available for appropriation } & $3,298,354$ \\
\hline \multicolumn{2}{|c|}{ Less dividend paid } & 35,000 & \\
\hline \multicolumn{2}{|c|}{ Dividend proposed } & $\underline{35,000}$ & $\underline{70,000}$ \\
\hline \multicolumn{3}{|c|}{ Balance carried forward 31.12.20x4 } & $€ 3,228,354$ \\
\hline \multicolumn{4}{|c|}{ Table 4 Cash flow statement for year ended 31 December 20x4 } \\
\hline \multicolumn{3}{|c|}{$\begin{array}{l}\text { Net change in cash for 20x4 } \\
\text { (Details as per Table 2, CFA Institute, p.25) }\end{array}$} & $€ 1,918,411$ \\
\hline \multicolumn{3}{|c|}{ Add opening cash balance on 1 January $20 x 4$} & $\underline{4,000,000}$ \\
\hline \multicolumn{3}{|c|}{ Closing cash balance on 31 December 20x4 } & $€ 5,918,411$ \\
\hline \multicolumn{4}{|l|}{ Table 5} \\
\hline \multicolumn{4}{|c|}{$\begin{array}{l}\text { Lease commitment for land and buildings, annual payment due } 31 \text { March } € 10,000 \\
\text { for } 4 \text { years to } 31 \text { March 20x8 (total commitment, €40,000). }\end{array}$} \\
\hline Table 6 & $\begin{array}{l}\text { Statement reconciling share capital a } \\
31 \text { December } 20 x 4 \text { with wealth at th }\end{array}$ & ts shown in th & lance sheet at \\
\hline Total fu & of common stockholders & & $€ 7,728,354$ \\
\hline \multicolumn{4}{|c|}{ Plus unrealised gains on assets shown at current market prices: } \\
\hline Mar & able securities & 11,100 & \\
\hline Inve & ries & 283,510 & \\
\hline Buil & & $\underline{435,000}$ & $\underline{729,610}$ \\
\hline & -total & & $8,457,964$ \\
\hline Less los & n write down of investment in affiliat & & $\underline{60,000}$ \\
\hline Wealth & t assets) attributable to common stock & & $€ 8,397,964$ \\
\hline
\end{tabular}

\section{Part 2: wealth measurement}

Information needs of shareholders recognised or assumed: The wealth statement is prepared to satisfy two specific information needs of shareholders. First, to enable calculation of Trans-Global Exports Ltd ability to settle its debts, and meet its commitments as they fall due; for assessment of the company's liquidity and solvency. Secondly, to enable calculation of net exchangeable asset backing per unit of common stock. 
Financial accounting reform

Table $7 \quad$ Wealth statement as at 31 December 20x4

\begin{tabular}{|c|c|c|}
\hline \multicolumn{3}{|l|}{ Assets } \\
\hline Bank & & $€ 5,918,411$ \\
\hline Accounts receivable & 845,000 & \\
\hline Less allowance for doubtful accounts & $\underline{70,500}$ & 774,500 \\
\hline Marketable securities (at market selling prices - net) & & 196,100 \\
\hline Inventories - at estimated selling prices ${ }^{(1)}$ & & 903,204 \\
\hline Investment in affiliate $(35 \%)^{(2)}$ - directors' valuation & & 650,000 \\
\hline Building - directors' valuation & & $\underline{4,260,000}$ \\
\hline Total assets & & $\underline{12,702,215}$ \\
\hline \multicolumn{3}{|l|}{ Less liabilities and preferred stock (per balance sheet) } \\
\hline Non-currentliabilities & & $2,504,800$ \\
\hline Currentliabilities & & $1,399,451$ \\
\hline Preferred stock & & $\underline{400,000}$ \\
\hline Total liabilities and preferred stock & & $\underline{4,304,251}$ \\
\hline Wealth, being net assets measured at current prices & & $€ 8,397,964$ \\
\hline
\end{tabular}

Notes: Assuming the number of shares of common stock issued is 600,000, asset backing per common stock share at current prices is €14 (€8,397, 964/600,000 = €14).

(1) With a margin of $45.75 \%$ on inventories, the current market selling prices have been estimated at $€ 903,204$.

(2) The return on the investment in the affiliate company appears low, thus the share price is assumed to have fallen since purchase to $\$ 650,000$. However, directors regard this as a long term strategic investment to help secure a source of supply, and expect to recover the full investment cost. Equity accounting is inappropriate as present ownership of shares is not sufficient for control.

Table 8 Statement reconciling changes in net assets of Trans-Global Exports Ltd. with monetary profit for the year ended 31 December 20x4

Net change in net assets before transactions with owners

$€ 378,801$

(Table 3, CFA Institute, p.27)

Add expense adjustments

Lease adj. (+5,944 amt. $+2,378$ int. $-7,500$ rent)

822

Deferred income tax

$\underline{33,120}$

Sub-tota

412,743

Less adjustments to fair value -

Revaluation of building

160,000

Revaluation of marketable securities $\quad 11,100$

Less reversal of equity in earnings of affiliate $\quad \underline{12,250}$

$\underline{183,350}$

Monetary profit for year 


\section{Comments on the examples}

References to the financial statements of Trans-Global Exports Ltd prepared by the Centre for Financial Market Integrity of the CFA Institute are identified by reference to the company name, and the name of the actual statement. The monetary profit statement plus balance sheet and wealth statement are identified by those names.

The examples of monetary profit measurement and the wealth statement shown in Appendix B are now contrasted, and also compared with Trans-Global's annual accounts for $20 \times 4$. First, the differences between the total funds of stockholders shown in the balance sheet of the monetary model and the wealth statement are highlighted in a reconciliation statement (Table 6), disclosing unrealised gains of $€ 729,610$ on marking assets to current market selling prices in the wealth statement less the write-down of the holding in the affiliate of $€ 60,000$, a net difference of $€ 669,610$ - almost three time the amount of the monetary profit. The inclusion of the shares held in the affiliate in the wealth statement at their current value is in contrast to their treatment in the balance sheet of the monetary model, where they continue to be recorded at cost as a strategic purchase which the directors believe has not lost long term value to the company. As the holding in the affiliate is insufficient to provide control through ownership, the 'quasi-valuation' of equity accounting is not justified under the principles of the monetary model.

A second reconciliation statement, Table 8, highlights the essential differences for 'profit' or 'net gain' measurement between Trans-Global's Table 3, p.27, showing the "Net change in net assets before transactions with owners" and monetary profit for 20x4. Adjustments to fair value in the former are reversed, likewise for the proportion of profits credited in respect of the affiliate's earnings. A minor adjustment converts the lease expense to a rental base in accordance with the lease contract. Deferred income tax is also reversed in the absence of a current obligation. The change in 'net assets' attributable to owners of $€ 378,801$ is thereby reduced to $€ 229,393$ monetary profit, a difference of $€ 149,408$ or $65 \%$ of monetary profit. Apart from the deletion of the share of the affiliate's earnings (for the reason already given above), the main adjustments are the elimination of the upwards revaluations from monetary profit as they are contrary to the realisation principle.

\section{Notes}

1 As quoted by Previts and Merino (1998, p.227).

2 Kothari and Lester (2012, p.350) concluded an evaluation of whether fair value accounting contributed to the GFC by stating "...it is clear that the poor implementation of fair value accounting standards have been a factor in causing and prolonging the Great Recession”. They also identified the ability of management to record gains immediately on "securitization" as a weakness.

3 "Postulates are few in number and are the basic assumptions on which principles rest" (AICPA, 1958). My framework reflects this relationship. The letter from the Special Committee of the American Institute of Accountants to the Committee on Stock List of the New York Stock Exchange of 22 September 1932 [May, (1943a), p.72] is credited with giving the term "generally accepted accounting principles" currency, particularly in the attest function [Storey and Storey, (1998), p.4]. Gilman (1939, p.199), reflecting the scepticism of practising accountants, doubted that there were any statements warranting the title of principles, although he was prepared to concede that, suitably adapted, the fundamental axiom of the AAA (1936/1957, p.61) might qualify. The axiom read: "Accounting is thus not 
essentially a process of valuation, but the allocation of historical costs and revenues to the current and succeeding fiscal periods".

4 Larson (1969, p.43) also supported the notion of exactness at the conceptual level, writing that it "simply means that the construct should be stated in such a way that its relation to other constructs will be clearly determinable".

5 Hence, the theory could also be described as a "deductive theory exploring user needs" which Whittington (1985, p.31) believed required "some development".

6 As Rudner's (1966) theory utilises a similar form to the Carnap/Hempel method criticised by Suppe (1977) I have prepared a response, available on request, to Suppe's nine guiding points on the use of the scientific method.

7 If all possible outcomes were known with certainty (including profits or losses on alternatives), the prospect of profit or increasing wealth would still exist as an initial motivating factor, but with plan outcomes matching expectations, the usefulness of accounting would be restricted to that of a record.

8 Economic income is unsuited for this task (see, for example, Kaldor, 1955; Shwayder, 1967; Ryan, 1970; Barton, 1974; Rayman, 2006; Ryan, 2007). Nor are the appeals to 'economic reality', or 'economic substance' convincing in the absence of agreement on the meaning of such terms.

9 Samuelson (1996) following Fisher (1906) presented a strong case for assets to be defined solely in terms of property rights. Under capitalism, however, if property has no economic value then it is not recognised as an asset.

10 Salvary $(1985,1992)$ selected recoverable cost as his qualitative, empirical property, but as recoverable cost is restricted to assets it does not include all the accounting elements. Willett $(1987,1988)$ selected cost as the qualitative, empirical property underlying the cost structure of his statistical activity cost theory (SACT). Willet (1988, p.87) noted that his resource set, defined in terms of cost, could be extended by being defined in terms of rights.

11 Coase (1992, p.714). More specifically, Williamson (1985, pp.17-18) wrote: “As compared with other approaches to the study of economic organization transaction cost economics (1) is more microanalytic, (2) is more self-conscious about behavioral assumptions, (3) introduces and develops the economic importance of asset specificity, (4) relies more on comparative institutional analysis, (5) regards the firm as a governance structure rather than a production function, and (6) places greater weight on the ex post institutions of contract with special emphasis on private ordering (as compared with court ordering)".

12 Acknowledging that their initial research had created some controversy, and taken some bumps, the three Harvard members of the original team revisited the issues, this time examining the law in 150 countries (42 common law, 84 French legal origin, 19 Scandinavian family and 5 unclassified) (La Porta, Lopez-de-Silanes and Shleifer, 2008; referred to as LLS, 2008). In brief, their basic hypothesis was confirmed and refined.

13 Canning (1929a) used the expression but due to the lack of detail it is not possible to identify whether he intended a specific concept.

14 For a discussion of these and related legal decisions, see Edwards (1989), French (1977), Gower (1969), Johnston et al. (1983) and Reiter (1926). The latter includes in Part II American Law and Practice on the distribution of profits.

15 Gower (1969, p.116) expressed a similar view in these terms: "After a few years, therefore, the Courts abdicated almost completely in favour of accountants and their businessmen clients".

16 Readers are referred to Edwards (1976) for a discussion of the impact of this case, including the 1926 Greene Committee, the significance of the Companies Acts 1928/1929 and the conflicting roles played by the two professional bodies. The acquittal of the auditor, Moreland, is described by his defence counsel, Hastings (1962).

17 Similar company law amendments were enacted in countries of the British Commonwealth, and led to 'revaluations' of fixed assets becoming widely used. For example, 46\% of disclosures of fixed assets (under the Ninth Schedule of the Companies Act 1961) of the 
250 Australian companies whose 1975 annual accounts were surveyed, were cost-based, 49\% were a combination of cost and valuation, and 5\% valuation only [Ryan et al., (1977), p.47].

18 The most significant of these is the 'decision useful' approach advocated by the Trueblood Study Group (AICPA, 1973) which has come to dominate conceptual frameworks. In response to the view that decision usefulness includes stewardship, Lennard (2007) pressed the case for its separate recognition. Persuasive arguments have been advanced for the broadening of the concept of stewardship to include social and environmental accounting, but this requires its own legislation since the perspective shifts from the ownership interest of shareholders to the general public interest.

19 Evidently, May (1950) did not appreciate the strength of the revenue concept derived from executed sales contracts, conceding that "realization is important only because it makes the results more precise" and describing it as a "triumph of law over economics" [Grady, (1962), p.236]. He was clearly drawn to "real income" as his preferred alternative [Grady, (1962), p.260].

20 de Paula (1948a, pp.18-19) apparently missed the opportunity to explain fully what he meant by the expression going concern value when, under cross examination by Sir Edward Hodgson (the only accountant on the 1945 Cohen Committee), he conceded that it meant "cost and reasonable depreciation", but without mentioning the recoverable cost rule or aspects of it. It is unclear whether he would have read the 1936 AAA statement. Zeff (1974, p.33) noted that during the 1920s de Paula "began to read widely in the American literature". However, in 1945 he was chair of the ICAEW Taxation and Financial Relations Committee, and his answers may have reflected the official position.

21 Suppose that an inventory item costing \$140 with a selling price of \$210 was included in inventory at $\$ 100$ on 31 December 2011, thereby causing a reduction in profit for the 2011 year of \$40. Suppose further, that in March 2012 it was sold for \$210, giving rise to an increase in profit of $\$ 110$ (being normal margin $\$ 70$ plus write down recovered of $\$ 40$ ). Thus, the write down in 2011is recovered in 2012, and one period's write down is another period's gain (or one period's pessimism is another period's optimism). It cannot be otherwise when the cash flows set the parameters. Isolating the impact of the decision to write down, net assets are reduced in 2011, and increased in 2012. Suppose that the item has genuinely lost value and is written down to $\$ 90$, its expected selling price on 31 December 2011, and sold for that amount in 2012. Then the loss of $\$ 50$ is expensed in the period in which it occurred, and no loss or gain results in 2012.

22 Due to the transaction/executed contract/change-in-property rights basis fundamental to monetary profit measurement, the kind of items described by Sprouse (1966) as "the what you may call its" have no place in this system (for example, assets and liabilities under tax allocation).

23 'Exchangeable' describes an asset which can be converted into cash through sale in a market. The term is similar to "severable" used by Chambers (1966, p.104) but as he also included in his definition of severable, conversion in "the process of production" or "alienation by way of gift”, exchangeable is the description preferred in this context.

24 CCEs, the term made famous by Chambers (1965), can be used interchangeably with two other terms for the measurement of wealth, namely: net current market selling prices, and net realisable values (NRVs), assuming that all three concepts are exit prices, 'net' of transactions costs and with realisation/settlement assumed not to be a forced liquidation. When applied to liabilities, 'selling prices' in the term in the second line is replaced by 'settling prices' and any transaction costs are added.

25 This comparison was suggested by the fourth "key conceptual tension" of "top down design v. bottom-up evolution" discussed by the AAA FASC (2012, p.125).

26 According to Godel's incompleteness theorem (Nagel and Newman, 1959) this applies to the simplest propositions in mathematics. Thus, the double entry calculus requires external propositions for its application. In the process this will create an additional set of definitions and primitive terms, requiring resort to a broader frame of reference for their determination, and so on. 